\title{
Extinction and survivorship of southern Tethyan benthic foraminifera across the Cretaceous/Palaeogene boundary
}

\author{
R. P. SPEIJER ${ }^{1,2} \&$ G. J. VAN DER ZWAAN ${ }^{1}$ \\ ${ }^{1}$ Department of Geology, Institute of Earth Sciences, Utrecht University, PO Box 80.021, \\ 3508 TA Utrecht, The Netherlands \\ ${ }^{2}$ Present address: Department of Marine Geology, Earth Sciences Centre, Göteborg \\ University, S-41381 Göteborg, Sweden
}

\begin{abstract}
The benthic foraminiferal record from the Cretaceous/Palaeogene boundary stratotype of El Kef, Tunisia, shows a succession of three distinct assemblages. The late Maastrichtian upper bathyal assemblage is highly diversified and shows no prominent signs of gradual change towards the boundary. The earliest Palaeocene is marked by the disappearance of more than $50 \%$ of the taxa, resulting in a strongly impoverished fauna, tolerant to low oxygen conditions and with a shallower water affinity. Sequential (re-) appearance of many taxa in the early Palaeocene signifies the restoration towards normal Palaeocene upper bathyal faunas. The faunal changes reflect major perturbations in redox and trophic conditions at the sea-floor.

At least locally, and perhaps even on a regional Tethyan scale, the extinctions can be related to a sharp decrease in oxygen supply, in combination with strongly reduced nutrient resources. It is suggested that a prolonged reduction in surface fertility and food flux to the sea-floor invoked worldwide (but diachronous) benthic extinctions. In particular endobenthic deposit feeders and other taxa adapted to high and perhaps heterogeneous nutrient resources suffered extinction.
\end{abstract}

Since the asteroid impact hypothesis was proposed to explain the mass-extinction at the end of the Cretaceous (Alvarez et al. 1980), the Cretaceous/Palaeogene $(\mathrm{K} / \mathrm{Pg})$ boundary has become one of the most controversial themes in Earth Sciences. Huge amounts of data support this extra-terrestrial event, a more (gradual) earthly cause, or a combination of both (see e.g. overviews in Sharpton \& Ward 1990; Sutherland 1994). In recent years, the focus has shifted somewhat in the direction of gaining a better understanding of extinction selectivity and of ecosystem recovery in the aftermath of the event (e.g. Gerstel et al. 1987; Archibald \& Bryant 1990; Gallagher 1991; Rhodes \& Thayer 1991; Sheehan \& Fastovsky 1992; Jäger 1993; Hansen et al. 1993; Raup \& Jablonski 1993).

In particular the well-documented planktonic foraminiferal extinction at the $\mathrm{K} / \mathrm{Pg}$ boundary has been the subject of intensive research (e.g. Luterbacher \& Premoli-Silva 1964; Smit 1982; Brinkhuis \& Zachariasse 1988; Keller 1988a, 1989a, b, 1993; D'Hondt \& Keller 1991; Huber 1991). In combination with a major turnover in calcareous nannofossils (e.g. Bramlette \& Martini 1964; Romein 1979b; Perch-Nielsen 1981; Alcala-Herrera et al. 1992; Pospichal 1994), a negative excursion in the $\delta^{13} \mathrm{C}$ record (e.g. Stott \& Kennett 1989; Zachos et al. 1989; Magaritz et al. 1992; Keller et al. 1993), and a drop in $\mathrm{CaCO}_{3}$ accumulation (e.g. Arthur et al. 1987; Keller \& Lindinger 1989), the extinction has been related to a major productivity crisis of the pelagic ecosystem (Perch-Nielsen et al. 1982; Hsü \& McKenzie 1985; Arthur et al. 1987; Meyers \& Simoneit 1989; Zachos et al. 1989). The productivity crisis appears to have been most profound at middle and low latitudes, but less dramatic at some high latitude sites (Hollis 1993; Keller 1993; Barrera \& Keller 1994). Since benthic foraminiferal communities largely depend on the vertical food supply from the overlying surface waters (see e.g. Van der Zwaan et al. 1992 and references therein) it seems plausible to expect that, in particular in tropical and subtropical regions, a drop in primary production had a profound effect on benthic communities.

Several studies discussed benthic foraminiferal changes across the K/Pg boundary (Dailey 1983; Keller 1988b, 1992; Thomas 1990b; Nomura 1991; Kaiho 1992; Schmitz et al. 1992; Widmark \& Malmgren 1992a; Kuhnt \& Kaminski 1993; Coccioni \& Galeotti 1994). There is a threefold general outcome of these studies: the first is that 


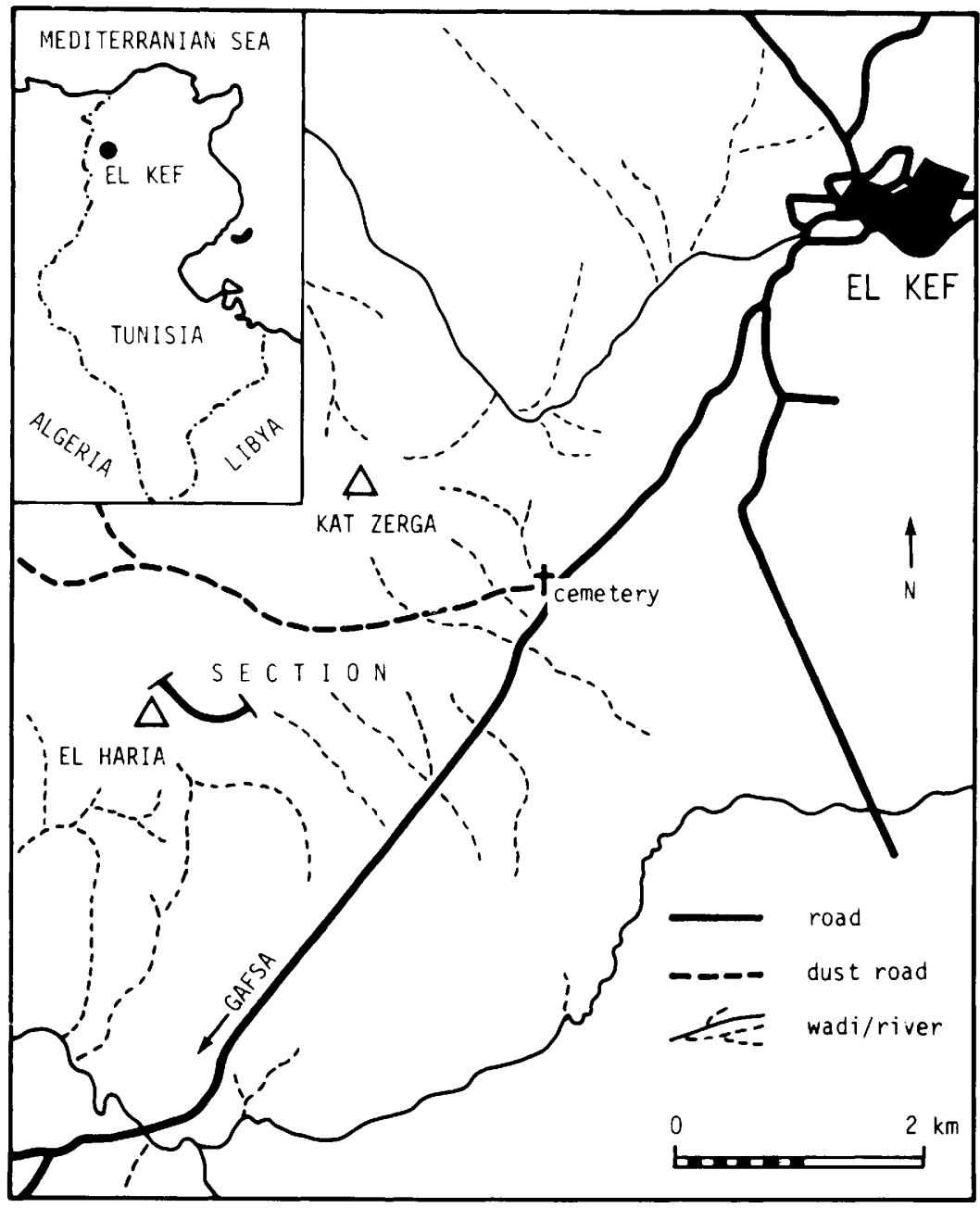

Fig. 1. Location map of the El Kef section (from Brinkhuis \& Zachariasse 1988).

in particular biserial and triserial species became extinct in the earliest Palaeocene (e.g. species of Praebulimina, Sitella, Eouvigerina, Orthokarstenia and Bolivinoides), next to some trochospiral species (e.g. species of Gavelinella and Stensioeina) (cf. Loeblich \& Tappan 1988), suggesting ecological selectivity. The second outcome is that the extinctions appear to have occurred over a prolonged time-span (Dailey 1983; Keller 1988b, 1992; Thomas 1990b; Nomura 1991; Schmitz et al. 1992; Widmark \& Malmgren 1992a). However, in some cases reworking of Cretaceous material into the Palaeocene may have contributed to this gradual pattern (Dailey 1983; Keller 1992). The third general result of previous studies is that deep-sea assemblages were less severely affected than continental margin assemblages (Thomas
$1990 b$; Kaiho 1992). Although some of the species previously mentioned are restricted to neritic deposits many others are only much less common in deep-sea deposits. These lower frequencies contribute to a less conspicuous turnover in quantitative studies. Thomas (1990a) suggested that the differential effects on the deep and shallower benthic communities might be related to the pelagic productivity breakdown, arguing that relatively oligotrophic deep-sea ecosystems would hardly be affected by a decrease in food supply, in contrast to shallower more eutrophic ecosystems. We discuss this hypothesis on the basis of a quantitative benthic foraminiferal analysis of the El Kef section (Tunisia) and semi-quantitative data from four $\mathrm{K} / \mathrm{Pg}$ boundary profiles in the Middle East. 
The El Kef section provides an expanded and probably continuous record across the $\mathrm{K} / \mathrm{Pg}$ boundary (Perch-Nielsen 1981; Romein \& Smit 1981; MacLeod \& Keller 1991 $a, b$; Olsson \& Liu 1993), enabling a detailed faunal analysis. A similar study on this section has been performed earlier by Keller $(1988 b)$. In that paper a major fall in sea-level and oxygen content was postulated to explain the benthic foraminiferal sequence across the $\mathrm{K} / \mathrm{Pg}$ boundary. Apart from using rather different taxonomic concepts, our interpretation of the data is substantially different. We also expanded the research further down into the Maastrichtian sequence to discern preboundary background variation and possible long-term trends (e.g. sea-level change). In order to improve our understanding of the faunal sequence of $\mathrm{El} \mathrm{Kef}$ we studied a variety of different upper Maastrichtian and lower Palaeocene assemblages from Egypt and Israel. At the same time, these enable us to evaluate overall changes in southern Tethyan palaeocommunities in a broader context. (A list of species discussed can be found in Appendix 1.)

\section{Material and methods}

\section{El Kef profile}

Samples were obtained from the MaastrichtianPalaeocene El Haria Formation (Salaj 1980), exposed in a section near the town of El Kef, Tunisia (Fig. 1). This paper focuses on the uppermost $30 \mathrm{~m}$ of the Maastrichtian marls and the lowermost $10 \mathrm{~m}$ of the Palaeocene shales and marls (Fig. 2). Basically, the widely distributed and studied AFN-coded samples were used. These samples were collected in 1982 by Drs A. J. T. Romein and J. Smit as representatives of the Cretaceous/Palaeocene Working Group of the International Committee on Stratigraphy. Drs A. J. Nederbragt and J. Smit kindly provided additional SN-coded samples, collected in 1992.

Apart from a $3 \mathrm{~m}$ thick basal Palaeocene unit, the sequence mainly consists of homogeneous grey to greenish-brown marls, without distinct sedimentological features. $\mathrm{The} \mathrm{K} / \mathrm{Pg}$ boundary is marked by a thin $(2 \mathrm{~mm})$ reddish ferruginous layer at the base of a $50 \mathrm{~cm}$ thick black shale bed (boundary clay). The boundary clay and the overlying $2.5 \mathrm{~m}$ dark grey to grey shales show preservation of sedimentary lamination and few pyritized and hematitic burrow molds. Abundant pyritized Chondrites-type burrow molds (diameter up to $1 \mathrm{~mm}$ ) are present in the overlying $6 \mathrm{~m}$ of marls, whereas these are absent in the upper metre of the profile studied.

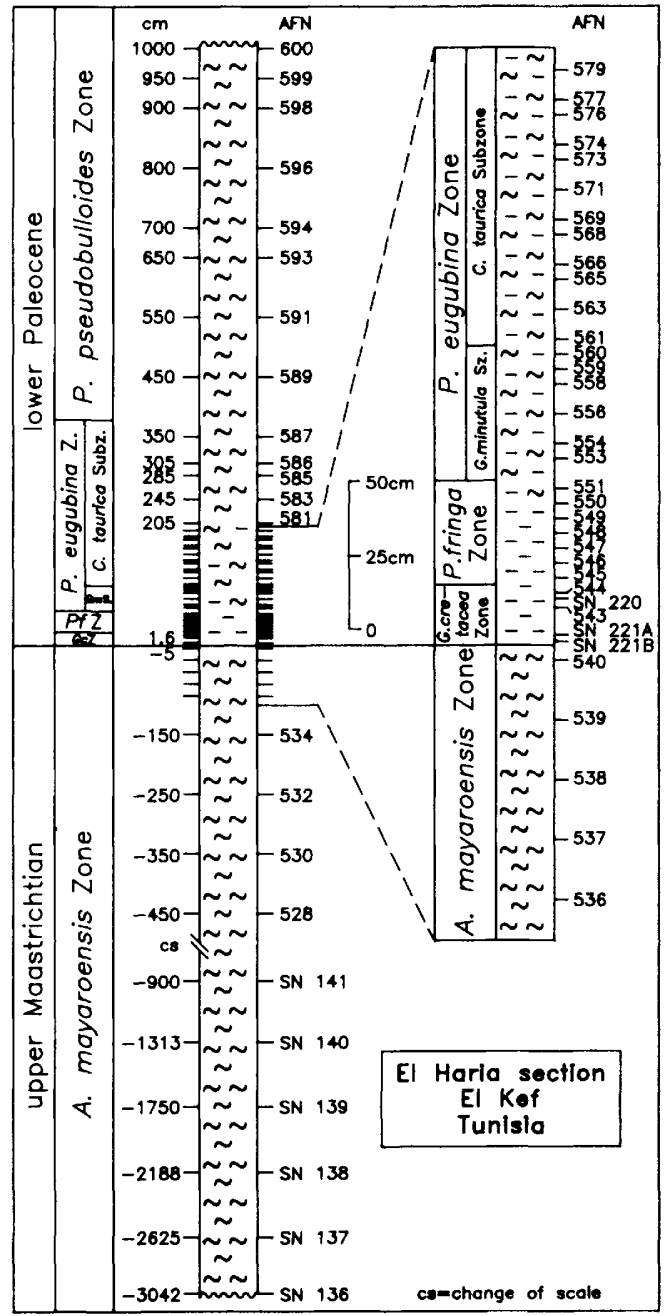

Fig. 2. Lithology and biostratigraphy of the El Kef section (modified from Brinkhuis \& Zachariasse 1988). Note the change in scale in the lower part of the section; figures on the left side of the column indicate distance $(\mathrm{cm})$ relative to the $\mathrm{K} / \mathrm{Pg}$ boundary.

The samples were washed and sieved into four size fractions. A split of the $125-595 \mu \mathrm{m}$ fraction, containing 200-400 specimens, was used for benthic foraminifera counts. All specimens were picked and stored in Chapman-slides. The benthic foraminifera were, whenever possible, identified at species level. Nodosariacea and poorly preserved agglutinants were lumped in a higher taxonomic level. For generic classification we largely followed Loeblich \& Tappan (1988) and in general, species concepts of Cushman (1946), Aubert \& Berggren (1976), and Salaj et al. (1976) were adopted. 


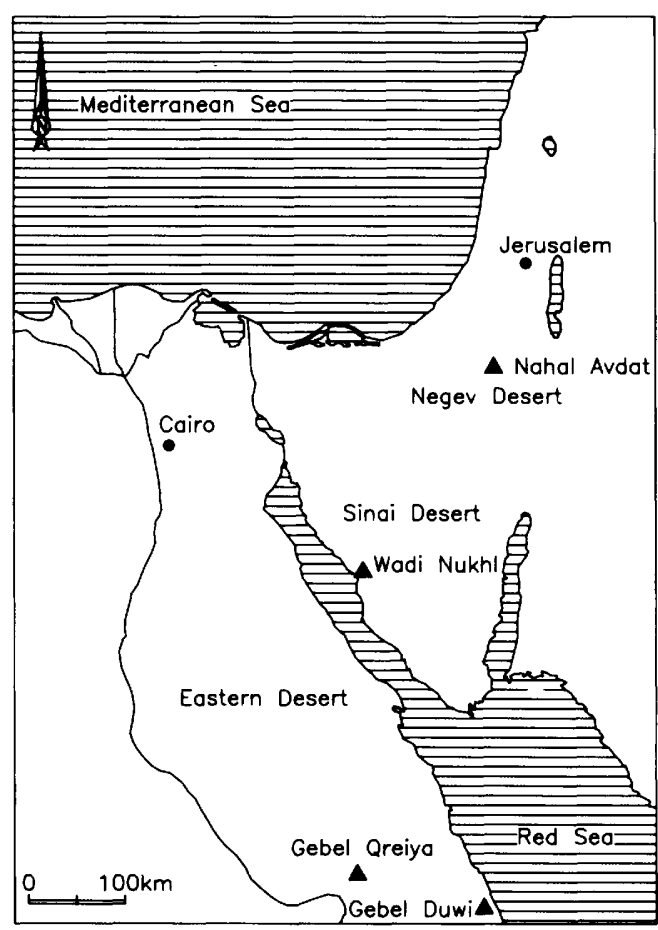

Fig. 3. Location map of $\mathrm{K} / \mathrm{Pg}$ boundary profiles in Egypt and Israel

After finishing census counts the initial dataset (containing 132 taxa) was condensed by lumping all highly infrequent taxa into higher order groupings. Fisher- $\alpha$ diversity (Murray 1991), however, is based on the original census data. Foraminiferal numbers (specimens/gr dry sediment) are calculated from separately dried and weighed samples, which were washed over a $63 \mu \mathrm{m}$ sieve. The $>63 \mu \mathrm{m}$ fraction was used in order to be able to establish planktonic foraminiferal numbers for the lowermost Palaeocene, because up to $3 \mathrm{~m}$ above the $\mathrm{K} / \mathrm{Pg}$ boundary planktonic foraminifera are $<125 \mu \mathrm{m}$ in diameter (Brinkhuis \& Zachariasse 1988).

\section{Israeli and Egyptian profiles}

Samples from other marly sequences covering the $\mathrm{K} / \mathrm{Pg}$ boundary interval were obtained from a profile in Israel (Nahal Avdat) and from three sections in Egypt (Gebel Duwi, Gebel Qreiya and Wadi Nukhl; Fig. 3). Calcareous nannoplankton studies of the Nahal Avdat profile indicate the $\mathrm{K} / \mathrm{Pg}$ boundary at about $1.5 \mathrm{~m}$ above the top of the Ghareb chalk (Romein $1979 a, b)$. The $\mathrm{K} / \mathrm{Pg}$ boundary in Wadi Nukhl is situated about $1 \mathrm{~m}$ above a ferruginous hardground, in the basal part of a Maastrichtian- upper Palaeocene marl-shale unit (cf. Shahin 1992). At Gebel Duwi the $\mathrm{K} / \mathrm{Pg}$ boundary is situated within the marls just below a distinct $1.2 \mathrm{~m}$ thick, black, decalcified shale (cf. Faris 1982). Samples from Nahal Avdat, Wadi Nukhl, and Gebel Duwi were processed in the same way as the ones from El Kef. At Gebel Qreiya the $\mathrm{K} / \mathrm{Pg}$ boundary lies approximately $2 \mathrm{~m}$ above a limestone bed in the Dakhla Formation (Luger 1988). Foraminiferal associations of this section were examined during a visit of the first author to Dr Luger in Bremen in 1993.

From all sections several upper Maastrichtian as well as lower Palaeocene samples were investigated. Faunal abundances of these samples are counted from pickings or estimated from strewings; all are treated semi-quantitatively and averaged per time interval. Since these sequences are either stratigraphically incomplete across the boundary, or show mixed Cretaceous and lowermost Palaeocene assemblages (see next section), it was not considered useful to study extinction and survivorship patterns in greater detail. Samples that contained mixed faunas were omitted in this study.

\section{Biostratigraphy}

\section{El Kef profile}

Since the El Kef section provides one of the most expanded and complete $\mathrm{K} / \mathrm{Pg}$ boundary profiles (Perch-Nielsen 1981; Romein \& Smit 1981; MacLeod \& Keller 1991a,b; Olsson \& Liu 1993), it was chosen to serve as a Global Stratotype Section and Point (GSSP) for the K/Pg boundary (Smit 1990). The position of the 'golden spike' is at the base of the boundary clay (i.e in the thin red ferruginous layer; Smit 1990). Our uppermost Maastrichtian sample spans the upper $10 \mathrm{~cm}$ of marls below the boundary clay, while the lowermost Palaeocene sample spans the lower $2.5 \mathrm{~cm}$ of the boundary clay. Therefore, the $\mathrm{K} / \mathrm{Pg}$ boundary as delineated by our samples roughly corresponds to the officially defined boundary.

Many biostratigraphers studied this section, or a nearby parallel section (e.g. Verbeek 1977; Salaj 1978, 1980; Wonders 1980; Perch-Nielsen 1981; Brinkhuis \& Zachariasse 1988; Keller 1988a; Pospichal 1994). We adopted the planktonic foraminiferal biozonation (Fig. 2) of Brinkhuis \& Zachariasse (1988). For an elaborate account of biozonal definitions we refer to Brinkhuis \& Zachariasse (1988); we confine ourselves to some brief remarks.

The lower $30.4 \mathrm{~m}$ of the section belongs to the uppermost Maastrichtian Abathomphalus 


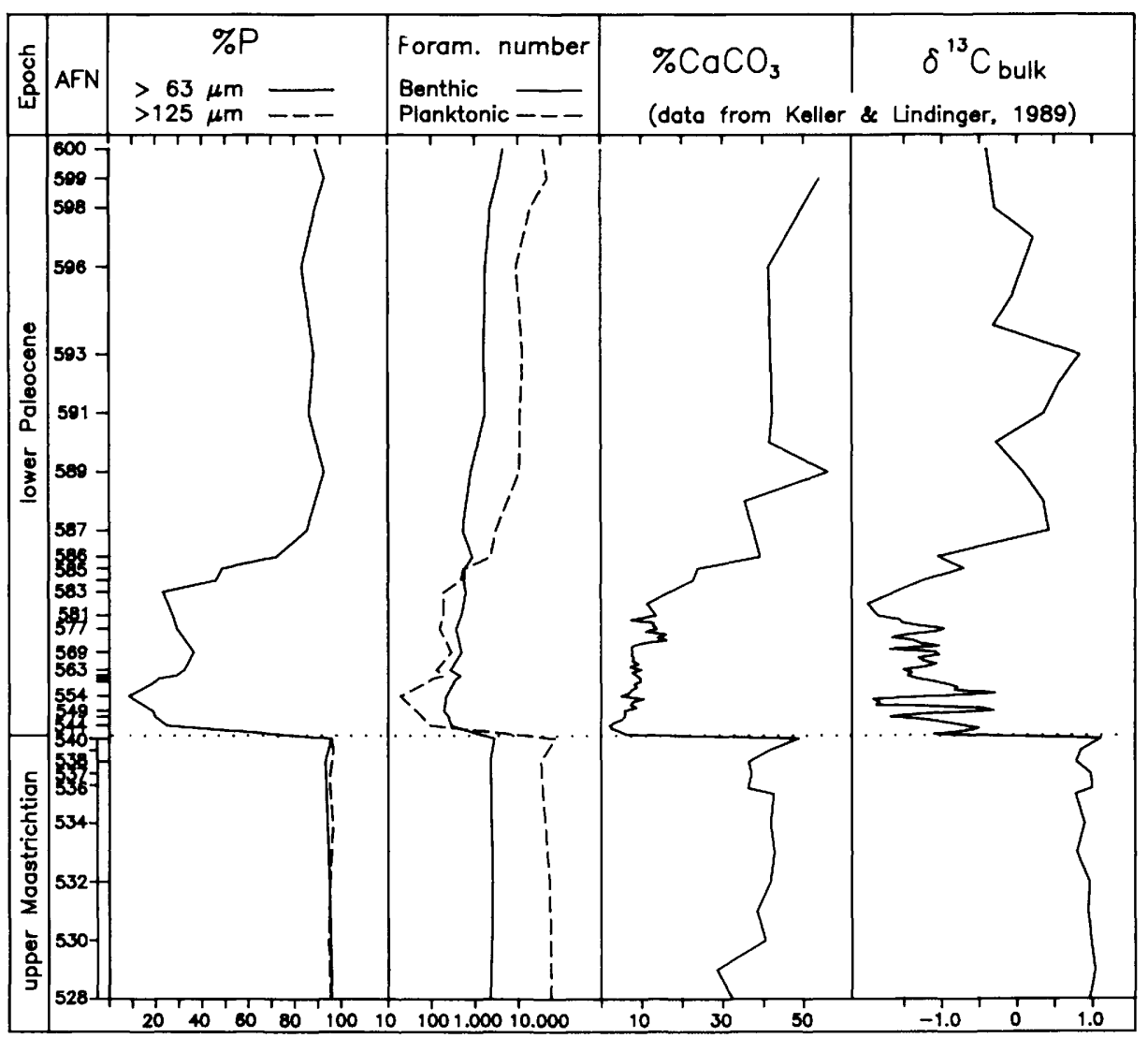

Fig. 4. The proportion of planktonic foraminifera $(\% \mathrm{P})$ and palaeoproductivity proxies for the $\mathrm{K} / \mathrm{Pg}$ boundary sequence of El Kef. Maastrichtian samples for which $\% \mathrm{P}$ in the $>125 \mu \mathrm{m}$ fraction has been calculated are indicated by sample ticks on the left side of the vertical line; samples for which the other calculations have been performed are marked by the sample ticks on the right side of this line.

mayaroensis Zone (Brinkhuis \& Zachariasse 1988 ). Since the zonal marker is very rare in $\mathrm{El}$ Kef, the local Racemiguembelina fructicosa Zone was proposed, and considered to overlap with the A. mayaroensis Zone (Nederbragt 1992). The base of the $R$. fructicosa Zone, is at approximately $100 \mathrm{~m}$ below the K/Pg boundary; a single specimen of $A$. mayaroensis was found eight metres higher up in the section (A. Nederbragt pers. comm. 1992). The presence of the calcareous nannoplankton species Micula prinsii in the upper $20 \mathrm{~m}$ of the Maastrichtian suggests that the youngest part of the Maastrichtian is present in the El Kef section (Perch-Nielsen et al. 1982; Pospichal 1994). Slightly deviating from Brinkhuis \& Zachariasse (1988), we define the base of the Guembelitria cretacea Zone by the first common occurrence of the nominate species in the $>63 \mu \mathrm{m}$ size fraction in the studied interval.
This level corresponds to the $\mathrm{K} / \mathrm{Pg}$ boundary. The subsequent Palaeocene zones as well as the Chiloguembelina taurica Subzone are marked by the entry of their respective nominate (sub)zonal markers at the base of each (sub)zone; the base of the Globoconusa minutula Subzone is defined by the entry of Parvularugoglobigerina eugubina. In this paper the lowermost two biozones and the lower to middle part of the P. eugubina Zone are generally taken together and referred to as lowermost (or earliest) Palaeocene. The upper part of the studied interval of the El Kef section comprises the basal $7 \mathrm{~m}$ of the $40 \mathrm{~m}$ thick Parasubbotina pseudobulloides Zone (Brinkhuis et al. 1994). For convenience, the upper part of the $P$. eugubina Zone (samples AFN 585-587), together with the $P$. pseudobulloides Zone will generally be referred to as lower (or early) Palaeocene. 


\section{Israeli and Egyptian profiles}

Abathomphalus mayaroensis has been recovered neither from the Israeli nor from the Egyptian Cretaceous samples. Environmental circumstances (e.g. too shallow conditions) have been proposed to explain the general absence or rarity of $A$. mayaroensis in upper Maastrichtian deposits from the southern Tethys and the Gulf Coastal plain (Keller 1989a,b). Therefore the uppermost Maastrichtian has to be differentiated in another way. Plummerita reicheli has been considered as an alternative index species for the uppermost Maastrichtian in many low latitude sites (Luger 1988; Rosenfeld et al. 1989; Masters 1993). According to Masters (1993) the first appearance of $P$. reicheli is well after the first appearance of $A$. mayaroensis. The former species has been observed in all Cretaceous samples studied, indicating that the uppermost Maastrichtian is present indeed in the Israeli and Egyptian sections. In Gebel Qreiya an uppermost Maastrichtian assignment is confirmed independently by the presence of $M$. prinsii (Luger 1988). The other sections yield other upper Maastrichtian calcareous nannoplankton markers such as Micula murus, Lithraphidites quadratus, or Nephrolithus frequens (Romein 1979b; Faris 1982; A. Henriksson pers. comm. 1993).

In Wadi Nukhl and Nahal Avdat we did not encounter the lowermost Palaeocene biozones. Although this may be related to a relatively wide sample spacing, it indicates that in the best case the lowermost Palaeocene is very condensed compared to El Kef. At Gebel Qreiya Palaeocene planktonic foraminifera of the $P$. eugubina Zone are mixed with up to $95 \%$ of Maastrichtian foraminifera (Luger 1988). Although some of the Cretaceous species may be true survivors (e.g. G. cretacea; cf. Smit 1982; Keller 1989a,b; Olsson \& Liu 1993), this most likely does not apply to large specimens of Globotruncana and Rugoglobigerina (Luger 1988; and cf. MacLeod \& Keller 1991b). More or less the same applies to Gebel Duwi, where we encountered extremely rare $(<1 \%)$ specimens of Parvularugoglobigerina fringa within an otherwise Maastrichtian fauna. Severe reworking of Maastrichtian foraminifera in lower Palaeocene deposits is a common feature in the Middle East and has been explained by sea-level related erosional events (Luger 1988; Keller et al. 1990). In all sections the $P$. pseudobulloides Zone was present and yielded samples with few, if any, reworked Cretaceous foraminifera.

\section{Palaeoproductivity}

Relative abundances of planktonic foraminifera (P/B ratios expressed as \% $\mathrm{P}$ ) and both planktonic as well as benthic foraminiferal numbers (named PFN and BFN, respectively) for a selected number of samples are shown in Fig. 4. Maastrichtian $\mathrm{P} / \mathrm{B}$ ratios are high and stable, varying between $93 \% \mathrm{P}$ and $97 \% \mathrm{P}$. Also $\mathrm{BFN}$ and PFN values are high: BFN values vary between 2300 and 2900 specimens/gr, whereas PFN ranges between 33000 and 73000 specimens/gr. The $\mathrm{K} / \mathrm{Pg}$ boundary is marked by a sharp fall in all three variables. The proportion of planktonic foraminifera drops to $20 \%$; BFN values are approximately 200-300 specimens/gr, while PFN values go down to 20-100 specimens/ gr, i.e. a reduction by one and three orders of magnitude, respectively. The proportion of planktonic foraminifera remains low up to $2.5 \mathrm{~m}$ above the $\mathrm{K} / \mathrm{Pg}$ boundary, from where the $\mathrm{P} / \mathrm{B}$ ratio gradually increases up to around $90 \% \mathrm{P}$ in the top of the profile. The restoration towards approximately pre-boundary levels in BFN (up to 4700 specimens/gr) and PFN (up to 49000 specimens/gr) is similar.

Fine fraction $\delta^{13} \mathrm{C}$ and $\mathrm{CaCO}_{3}$ records of $\mathrm{El}$ Kef (Fig. 4) indicate relatively high surface water productivity during the Maastrichtian followed by strongly reduced productivity from the $\mathrm{K} / \mathrm{Pg}$ boundary onwards into the earliest Palaeocene (Keller \& Lindinger 1989). Planktonic foraminiferal accumulation rates (PFARs) have also been used to estimate surface productivity levels (Berger \& Diester-Haass 1988), but in order to obtain reliable PFAR values a good time control for calculating sedimentation rates is crucial. Unfortunately, there is considerable uncertainty with respect to the exact amount of time involved within the El Kef sequence (e.g. MacLeod \& Keller 1991b; Olsson \& Liu 1993; Berggren et al. 1995), and estimated average sedimentation rates vary accordingly. The estimated average sedimentation rate for the Upper Maastrichtian is about $4 \mathrm{~cm} / \mathrm{ka}$ (Brinkhuis \& Zachariasse 1988). For the boundary clay estimates vary between 0.7 and $1.7 \mathrm{~cm} / \mathrm{ka}$, whereas for the $P$. eugubina Zone they vary between 1.9 and $4 \mathrm{~cm} / \mathrm{ka}$ (Brinkhuis \& Zachariasse 1988; MacLeod \& Keller 1991b; Olsson \& Liu 1993). In the lower part of the $P$. pseudobulloides Zone average sedimentation rate may have decreased to $1.1 \mathrm{~cm} / \mathrm{ka}$ (MacLeod \& Keller $1991 b$ ). Due to these uncertainties we refrain from calculating PFARs and consider planktonic foraminiferal numbers as an alternative, though very crude, way of assessing productivity changes in a relative sense. We calculated an 
almost three orders of magnitude decrease in $\mathrm{PFN}$ at the $\mathrm{K} / \mathrm{Pg}$ boundary, at a level where sedimentation rates are generally considered to have reduced. Although some taphonomical loss by dissolution probably contributed to this decrease, it concurs with the geochemical interpretation of a sharp pelagic production decline during the earliest Palaeocene. At about $2.5 \mathrm{~m}$ above the $\mathrm{K} / \mathrm{Pg}$ boundary (i.e. in the upper part of the $P$. eugubina Zone), PFN values gradually increase, together with an increase in the $\mathrm{CaCO}_{3}$ and $\delta^{13} \mathrm{C}$ records. This could indicate a gradual restoration towards former (Maastrichtian) surface fertility levels as proposed by Keller \& Lindinger (1989). However, both PFN and $\delta^{13} \mathrm{C}$ values remained slightly depressed relative to the Maastrichtian, suggesting that surface productivity probably did not fully recover within the studied interval.

Benthic foraminiferal numbers decrease in a similar way as PFN, though with lesser magnitude, across the $\mathrm{K} / \mathrm{Pg}$ boundary. This coincidence is not surprising since benthic foraminifera that live below the euphotic zone primarily depend on the vertical organic carbon flux for their food supply (Van der Zwaan et al. 1990; Herguera \& Berger 1991). In addition, oxygen deficiency may have contributed to reduced benthic productivity as well (Van der Zwaan et al. 1990). With increasing surface productivity, BFN values also increase again.

\section{Benthic foraminiferal assemblages from El Kef}

\section{Stratigraphic distribution}

The frequency data (Table 1) of the sixty most common taxa in the $\mathrm{K} / \mathrm{Pg}$ boundary interval are displayed graphically in Fig. 5. The taxa are arranged and grouped according to their presence within three biostratigraphic intervals. These intervals are approximately the $A$. mayaroensis Zone, the $G$. cretacea Zone to the upper part of the P. eugubina Zone (=lower Palaeocene). In this way, we discriminate six stratigraphic assemblages (SA 1-6), each having its specific range, but note that this does not mean that the ranges of individual taxa span the entire range of the stratigraphic assemblages to which they belong.

Stratigraphic assemblage 1 (SA 1) consists of taxa that are virtually restricted to the $A$. mayaroensis Zone. Gavelinella martini occurs persistently in all Maastrichtian samples; all other taxa have a discontinuous distribution within the data set. Only one species (Stensioeina pommerana) disappeared permanently well below the K/Pg boundary. Six taxa (Bolivinopsis clotho, Heterostomella spp., Eouvigerina subsculptura, Praebulimina reussi, Coryphostoma plaitum and Anomalinoides sp. 1) disappeared at the $\mathrm{K} / \mathrm{Pg}$ boundary. Scattered occurrences (only one or two specimens per sample) of six other species (Bolivinoides draco draco, Sitella colonensis, S. cushmani, Cibicides beaumontianus, Gyroidinoides tellburmaensis and G. martini) were encountered up to $3.6 \mathrm{~cm}$ above the boundary; only Sitella fabilis was found in considerable numbers $(2.5 \%)$ at $1.2 \mathrm{~cm}$ above the boundary. One poorly preserved specimen of Coryphostoma incrassata gigantea was encountered at $12.5 \mathrm{~cm}$ above the boundary.

Stratigraphic assemblage 2 (SA 2) contains taxa that are virtually absent in the lowermost Palaeocene, whereas they are more or less common in the $A$. mayaroensis Zone as well as in the lower Palaeocene. Four species (Loxostomoides applinae, Cibicidoides sp. 1, Oridorsalis plummerae and Anomalinoides sp. 2) of this assemblage disappeared temporarily well below the $\mathrm{K} / \mathrm{Pg}$ boundary. Most taxa, however, disappeared near the K/Pg boundary: three taxa at the boundary (Cibicidoides of. hyphalus biconvex morphology -, Gyroidinoides spp., and 'calcareous agglutinants rest'), four taxa between 1.2 and $3.6 \mathrm{~cm}$ above the boundary (Pseudouvigerina plummerae, Cibicidoides suzakensis, Pullenia spp. and Anomalinoides affinis), and seven taxa (Gaudryina pyramidata, Cibicidoides abudurbensis, $C$. cf. hyphalus - planoconvex morphology -, Valvalabamina depressa, Gyroidinoides octocameratus, miliolids and 'trochospiral rest') between 3.6 and $12.5 \mathrm{~cm}$ above the boundary. Only very low frequencies of most of these taxa (one to three specimens per sample) are recorded in the lowermost Palaeocene. The uppermost part of the P. eugubina Zone (from AFN 583 onwards) and the $P$. pseudobulloides Zone show a gradual reappearance of all (socalled Lazarus) taxa of this assemblage.

The taxa in stratigraphic assemblage 3 (SA 3) show a fairly continuous distribution pattern along the entire sequence and most of them have relatively constant frequencies as well. Note that most taxa in SA 3, except for Bolivinoides decoratus and Anomalinoides simplex, are lumped categories. Taxa of stratigraphic assemblage 4 (SA 4) have a similar stratigraphic distribution to SA 3, but all show either a highest abundance or a frequency increase in the lowermost Palaeocene. Most taxa of SA 4 decrease in relative abundance in the lower Palaeocene. Stratigraphic assemblage 5 (SA 5) consists of taxa that first appear in the basal part 


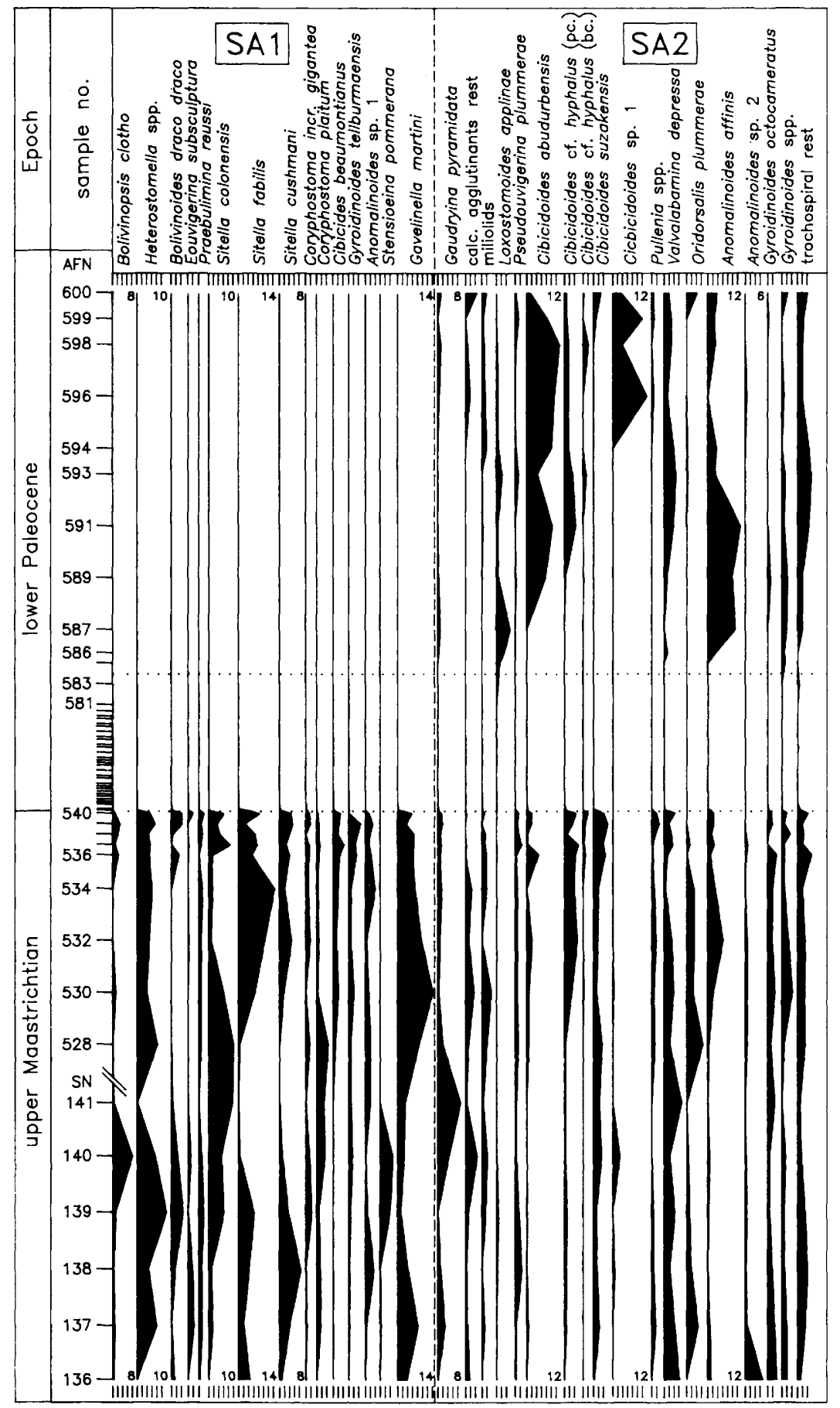

Fig. 5. Frequency range chart of the 60 most common taxa in the El Kef $\mathrm{K} / \mathrm{Pg}$ boundary profile. SA 1-6 indicate groupings of taxa with corresponding distributional patterns. Note the change of scale in the upper Maastrichtian as in Fig. 2. 


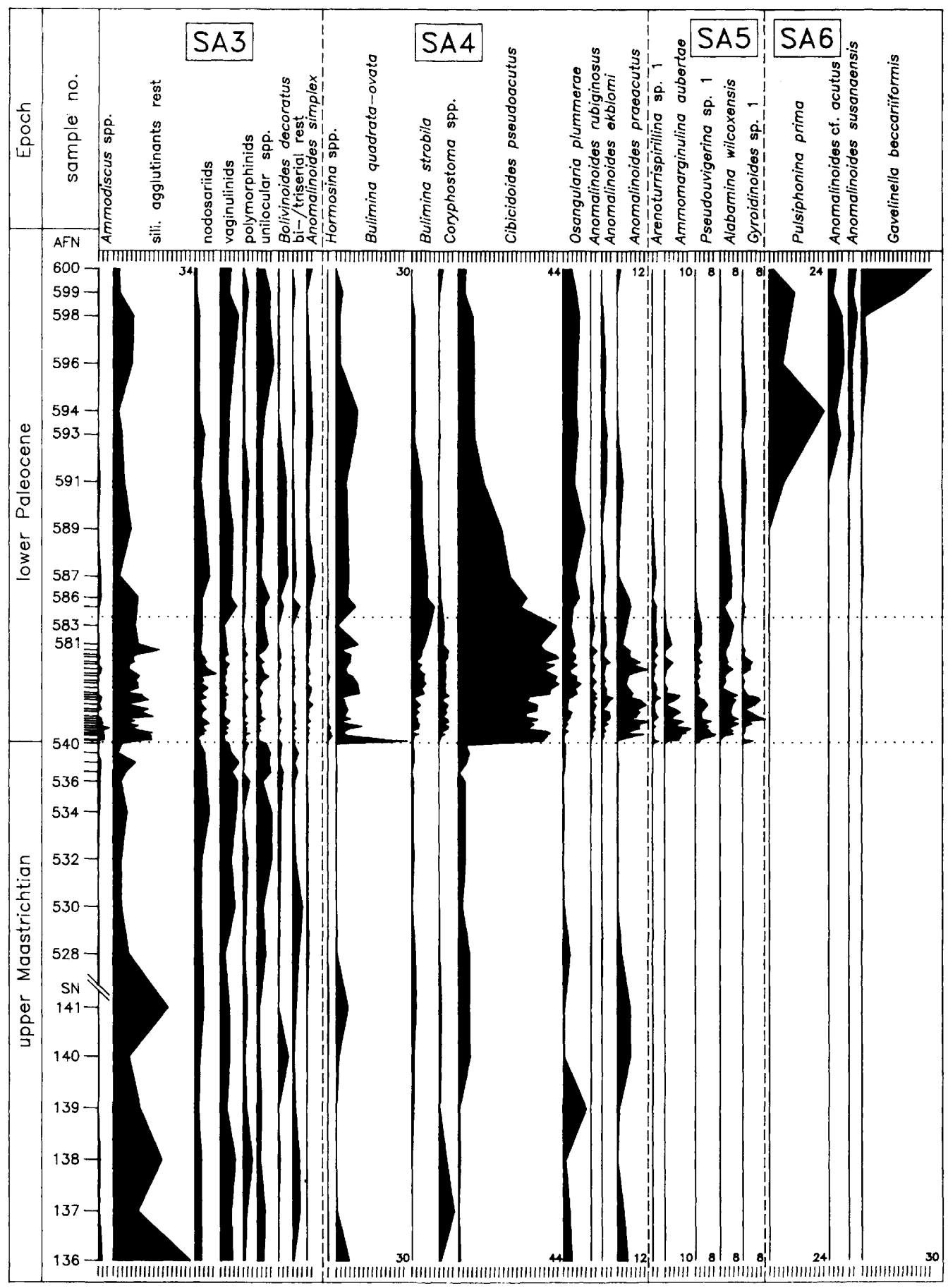


落

กั

㱐

$0000000000000000 \mathrm{~m} 00$

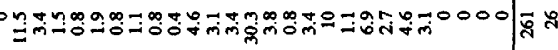

苂

จิ ที่

मैं

जे

ฟั

กั้

₹ั้

สิ

कึ บุ

ल)

ำ

赵 ?

商 พิ

000000000000000000000000000000000

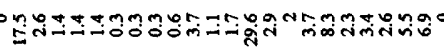

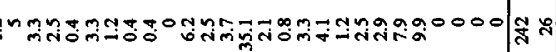

i.

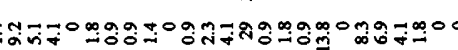

000

$\infty$

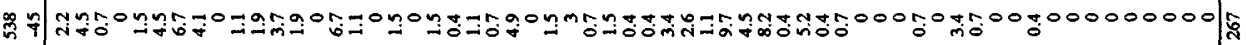

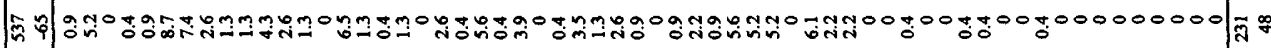

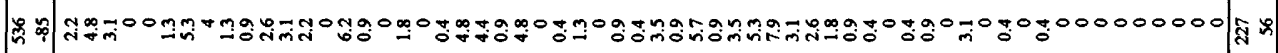

芦

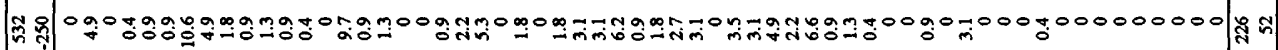

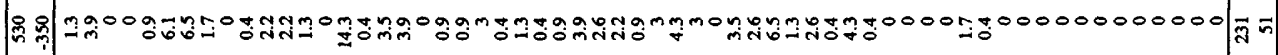

Ж

I

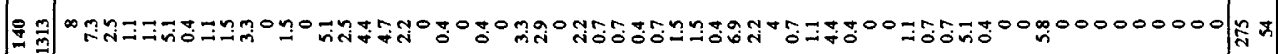

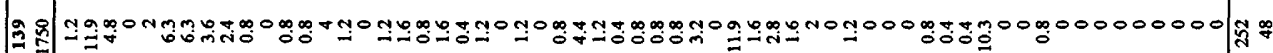

$2 \frac{4}{0}$ :

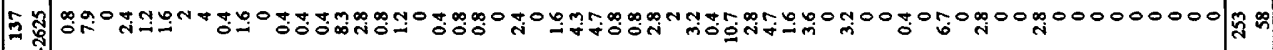

荧

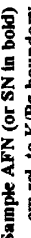

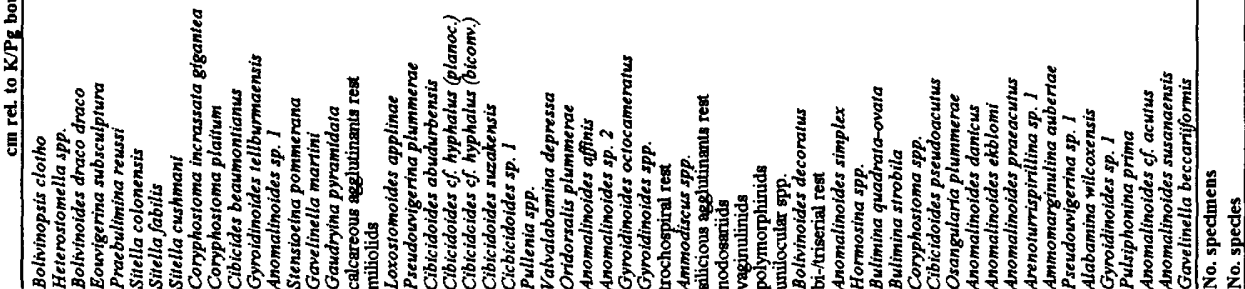




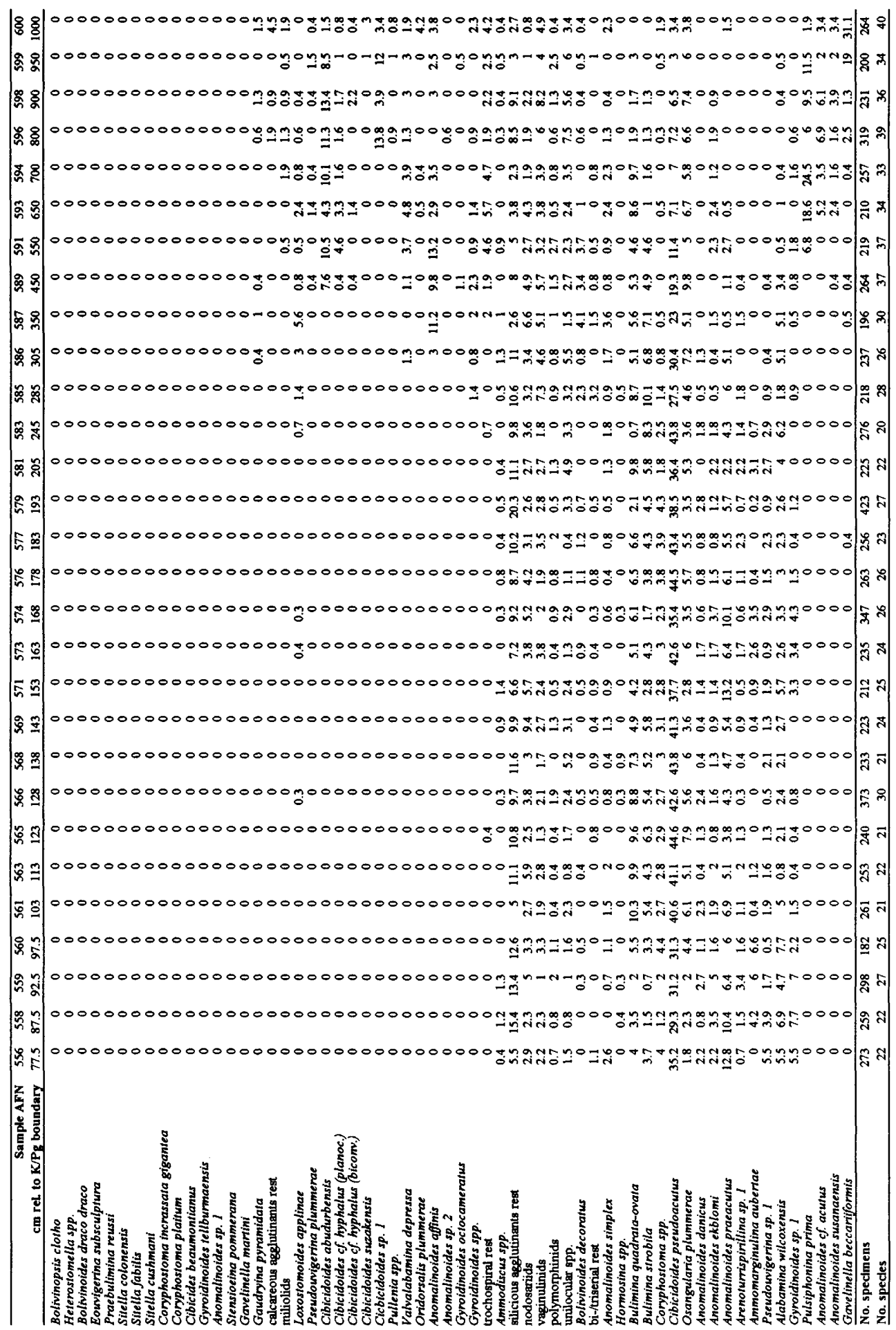




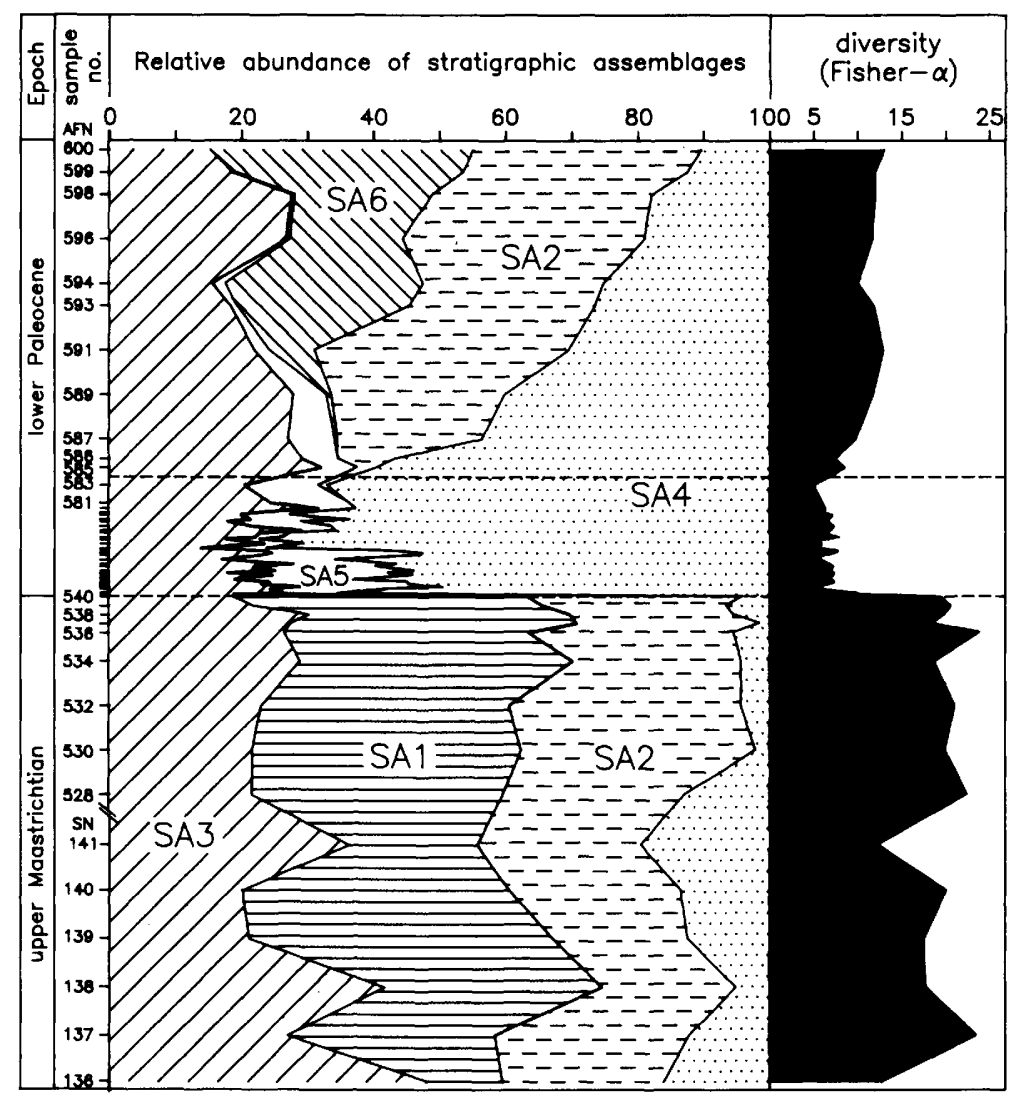

Fig. 6. Cumulative relative abundance of the stratigraphic assemblages (SA 1-6) and Fisher- $\alpha$ diversity visualize the abrupt community impoverishment at the $\mathrm{K} / \mathrm{Pg}$ boundary and the more gradual community diversification at El Kef. Note the change of scale in the upper Maastrichtian as in Fig. 2.

of the boundary clay. Four species (Arenoturrispirillina sp. 1, Ammomarginulina aubertae, Pseudouvigerina sp. 1 and Gyroidinoides sp. 1) appear in the basal sample overlying the $\mathrm{K} / \mathrm{Pg}$ boundary. Alabamina wilcoxensis appears $10 \mathrm{~cm}$ higher up. All taxa of SA 5 either disappear, or at least decline in relative numbers in the lower Palaeocene. Finally, stratigraphic assemblage 6 (SA 6) is composed of taxa that have their first appearance in the top of the $P$. eugubina Zone (Gavelinella beccariiformis) or in the $P$. pseudobulloides Zone (Pulsiphonina prima, Anomalinoides susanaensis and $A$. cf. acutus).

\section{Faunal turnover}

For each stratigraphic assemblage the cumulative frequencies are displayed in Fig. 6; in addition Fisher- $\alpha$ diversity values, based on the primary data set, are shown. The graph shows three main stages in benthic foraminiferal palaeocommunity development: the first stage comprises the late Maastrichtian interval, the second the earliest Palaeocene, and the third the early Palaeocene. The first and second stages display a relatively stable taxonomical composition (Fig. 5), whereas the third stage shows a gradual taxonomic change from bottom to top.

Stage one: the upper Maastrichtian assemblage (SN 136 to AFN 540) is highly diversified (average $\alpha=19.2$ ). Apart from the abundant poorly preserved, and unspecified, silicious agglutinants in the lower part of the profile, the Maastrichtian assemblage is dominated by taxa of SA 1 (all together up to 46\%): in particular, Heterostomella spp., S. colonensis, $S$. fabilis and G. martini reach peak abundances of $10-15 \%$. Although frequencies of individual taxa vary strongly, the assemblage as a whole is relatively stable up to the $\mathrm{K} / \mathrm{Pg}$ boundary (Fig. 6). Within less than $12.5 \mathrm{~cm}$ above the $\mathrm{K} / \mathrm{Pg}$ boundary, $67 \%$ of the taxa that are present in the uppermost metre of the Maastrichtian disappear (partly temporarily) from the record 
(disregarding lumped taxa at supra-generic level). Whereas these taxa comprise more than $70 \%$ of the total assemblage in the uppermost Maastrichtian sample, they constitute only $8 \%$ of the sample $1.2 \mathrm{~cm}$ above the $\mathrm{K} / \mathrm{Pg}$ boundary and only $3 \%$ at $3.6 \mathrm{~cm}$. This rapid decrease marks a sharp faunal transition at the base of the boundary clay. The original transition, however, may well have been even sharper, since it is not unlikely that rare occurrences of SA 1 and SA 2 taxa in the boundary clay are reworked. Distinguishing reworked from in situ benthic foraminifera from this record by means of geochemical studies is very difficult, if not impossible, because of the state of preservation of the foraminifera tests. But, when we consider benthic foraminiferal numbers below and above the boundary (Fig. 4), it shows that merely a one percent mixing of Maastrichtian sediment into the basal boundary clay may account for the total number of SA1 and SA2 specimens found.

Stage two: the lowermost Palaeocene assemblage (SN 221b to AFN 583) is poorly diverse (average $\alpha=6.6$ ). All samples are dominated by SA 4 taxa (together up to $77 \%$ ), and for all but the lowermost sample the dominant species is Cibicidoides pseudoacutus (29-45\%). The lowermost sample is dominated by Bulimina quadrata-ovata, showing a distinct spike in its distribution pattern at the base of the boundary clay. Other species reaching relative abundances greater than $10 \%$ are Anomalinoides praeacutus and $A$. aubertae. Most common taxa in this assemblage, except for the supra-generic groups, were either absent or infrequent in the Maastrichtian, in particular in the upper metre of this interval. Faunal composition is fairly constant within the lowermost Palaeocene. There is, however, a marked increase in relative abundance of $C$. pseudoacutus, coinciding with a decrease of SA 5 taxa (Figs 5,6) at the base of the $C$. taurica Subzone.

Stage three: the faunal transition from the lowermost Palaeocene to the lower Palaeocene is very gradual compared to the $\mathrm{K} / \mathrm{Pg}$ boundary transition. The boundary between the second and third stages is drawn at the first distinct decrease of $C$. pseudoacutus and the concomitant increase in diversity (at $2.65 \mathrm{~m}$ above the $\mathrm{K} / \mathrm{Pg}$ boundary, in between AFN 583 and AFN 585). The lower Palaeocene assemblage is moderately diversified (average $\alpha=10.9$ ), but gradually increasing upwards. Initially, SA 4 species are still dominant (in particular C. pseudoacutus), but the proportion of reappearing Lazarus taxa (SA 2) steadily increases up to the level where new taxa of SA 6 appear at the expense of the proportion of taxa of SA 3-5. Cibicidoides sp. 1,
C. abudurbensis, $A$. affinis, Bulimina strobila, $C$. pseudoacutus, $P$. prima and $G$. beccariiformis reach peak abundances of $10-31 \%$. The lower Palaeocene assemblage clearly evolves within the $P$. pseudobulloides Zone and it does not appear to have stabilized at the top of the studied interval, judging from the increase of $G$. beccariiformis in the uppermost samples. Further developments of benthic foraminiferal assemblages in the Palaeocene are beyond the scope of this study and will be treated in detail in a separate paper.

\section{Benthic foraminiferal assemblages from the Middle East}

Semi-quantitative benthic foraminiferal data of the $\mathrm{K} / \mathrm{Pg}$ boundary profiles of Nahal Avdat, Wadi Nukhul, Gebl Qreiya and Gebel Duwi are listed in Table 2. The table lists the taxa of El Kef, and in addition the more common taxa (average $>2 \%$ ) occurring in any of the other localities. As explained earlier, we can only address upper Maastrichtian and lower Palaeocene distribution patterns and discuss the overall faunal change across the $\mathrm{K} / \mathrm{Pg}$ boundary.

\section{Upper Maastrichtian}

Upper Maastrichtian assemblages from Wadi Nukhl and Nahal Avdat bear great resemblance to those from El Kef. Although relative abundances of many taxa may differ significantly between the localities, the overall taxonomical composition is very similar. In Wadi Nukhl the most common species (>5\%) are $P$. reussi, $C$. incrassata gigantea, $C$. abudurbensis, C. pseudoacutus and Osangularia plummerae. In Nahal Avdat the most common species are $B$. draco draco, Eouvigerina subsculptura, S. cushmani and C. abudurbensis. The proportion of planktonic foraminifera $(80-95 \% \mathrm{P})$ in Wadi Nukhl and Nahal Avdat is similar to, though more variable than, those of El Kef.

The upper Maastrichtian assemblage from Gebel Qreiya differs significantly from the former assemblages; diversity is much lower and in particular most taxa of SA 1 are absent. Instead we find Orthokarstenia oveyi, Pyramidina aegyptiaca, Elhasaella cf. allanwoodi, Neobulimina canadensis and Anomalinoides umboniferus; none of these species was ever encountered in the assemblages from El Kef, Wadi Nukhl or Nahal Avdat. The most common species are B. strobila, C. pseudoacutus, and 
Table 2. Semi-quantitative data of $\mathrm{K} / \mathrm{Pg}$ profiles in Israel and Egypt

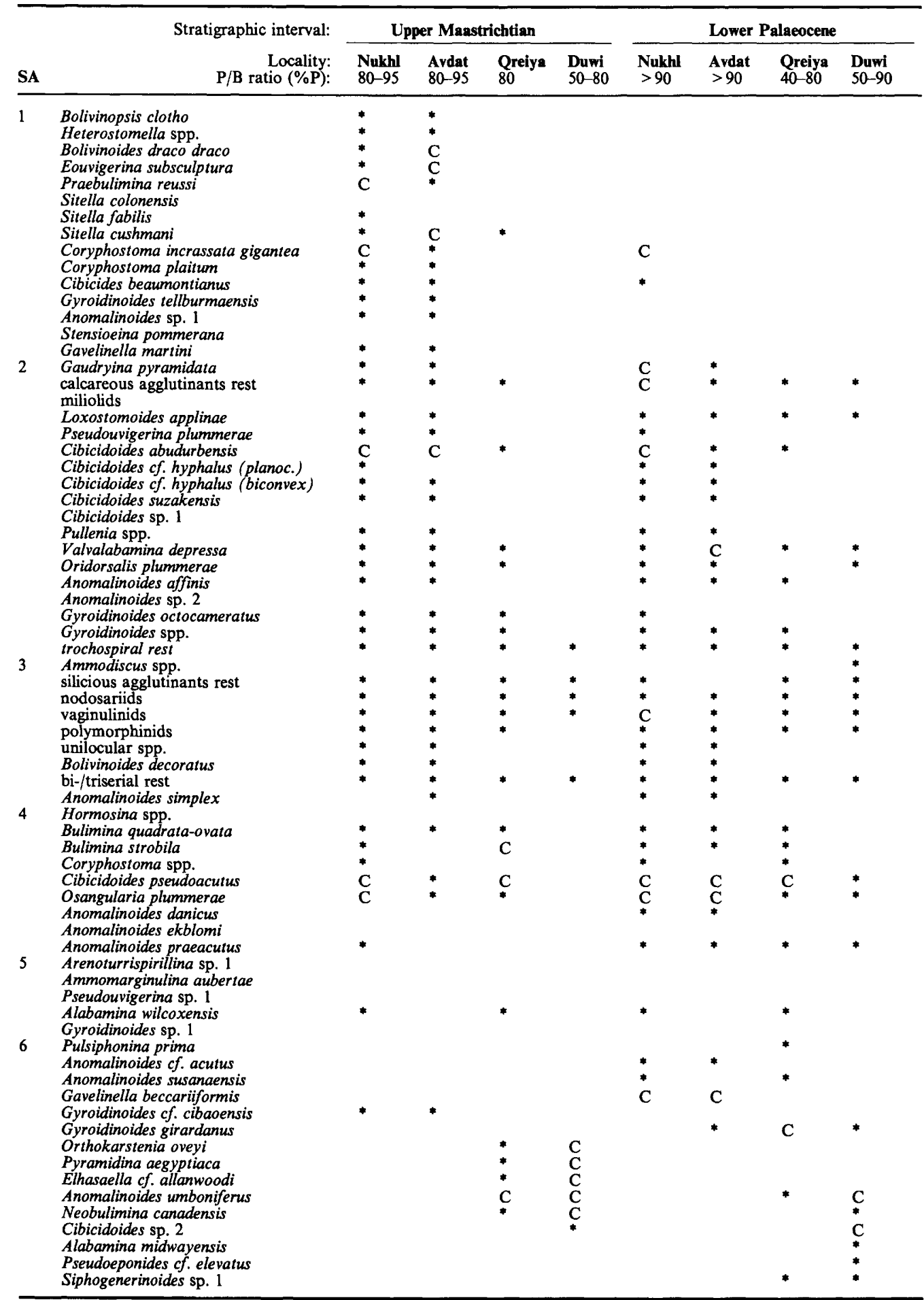

Data of the lowermost Palaeocene are not considered because of suspected reworking and/or hiatuses (see text).

* marks average abundance $<5 \%$; $\mathrm{C}$ marks average abundance $>5 \%$. 
A. umboniferus. $\mathrm{P} / \mathrm{B}$ ratio's $(80 \% \mathrm{P})$ in Gebel Qreiya are lower than in El Kef, Wadi Nukhl and Nahal Avdat.

The upper Maastrichtian assemblage of Gebel Duwi has even fewer taxa in common with El Kef, Wadi Nukhl and Nahal Avdat (actually only in the lump categories), whereas $O$. oveyi, $P$. aegyptiaca, $E$. allanwoodi, $N$. canadensis and $A$. umboniferus are highly abundant. The proportion of planktonic foraminifera $(50-80 \% \mathrm{P})$ in Gebel Duwi is somewhat lower than in Gebel Qreiya.

\section{Lower Palaeocene}

Similar to the upper Maastrichtian situation, the lower Palaeocene faunas of Wadi Nukhl and Nahal Avdat bear great resemblance to the one from El Kef; most taxa of SA 2, 3, 4 and 6 are present, some of the more common ones also in similar relative frequencies: e.g. $C$. abudurbensis, C. pseudoacutus, Osangularia plummerae and $G$. beccariiformis. Next to these we find very common $C$. incrassata gigantea, $G$. pyramidata, other large calcareous agglutinants and vaginulinids in Wadi Nukhl, while $V$. depressa is highly frequent in Nahal Avdat. Two SA 1 species (C. incrassata gigantea and $C$. beaumontianus) range into the lower Palaeocene of Wadi Nukhl (in these cases reworking can be excluded), indicating that their extinction in $\mathrm{El}$ Kef is just a local feature. The same applies to Bolivinopsis clotho and $P$. reussi, which have occasionally been observed in lower and upper Palaeocene assemblages from Wadi Nukhl and Nahal Avdat (unpubl. data). P/B ratios are $>90 \%$ P.

The lower Palaeocene assemblages of Gebel Qreiya are less diverse than the ones of $\mathrm{El}$ Kef, Wadi Nukhl and Nahal Avdat, although they are more similar than the Maastrichtian assemblages. Cibicidoides pseudoacutus is the dominant species, while Gyroidinoides girardanus is also a common species. The proportion of planktonic foraminifera $(40-80 \% \mathrm{P})$ is considerably lower than in El Kef, Wadi Nukhl and Nahal Avdat.

The lower Palaeocene fauna of Gebel Duwi is again the one that is most different from $\mathrm{El} \mathrm{Kef,}$ but as for Gebel Qreiya the similarity is greater and diversity is higher than in the Maastrichtian. Cibicidoides sp. 2 and $A$. umboniferus are the most abundant taxa. Relative numbers of planktonic foraminifera $(50-90 \% \mathrm{P})$ are somewhat higher than in Gebel Qreiya.

\section{Stages in southern Tethyan \\ palaeoenvironment and benthic palaeocommunity development}

\section{Late Maastrichtian}

As indicated in the previous section, the upper Maastrichtian benthic foraminiferal faunas from Wadi Nukhl and Nahal Avdat show a great resemblance to the ones from El Kef. Very similar assemblages were documented from other localities in southern Israel as well (Benjamini et al. 1992; Keller 1992), while the ones reported from northern Egypt (LeRoy 1953; Said \& Kenawy 1956) also appear comparable.

Little is known about Maastrichtian palaeobathymetrical distribution of benthic foraminifera in North Africa. For a palaeobathymetrical estimate, we compared our assemblages with the ones documented in Campanian-Maastrichtian palaeoslope models of North America (Silter \& Baker 1972; Olsson 1977; Nyong \& Olsson 1984; Olsson \& Nyong 1984). Our assemblages contain a few species that are most common in North American shelf environments, e.g. C. incrassata gigantea, $C$. plaitum and $V$. depressa. Other taxa are common in outer neritic and upper bathyal environments, e.g. P. plummerae, $B$. draco draco, Anomalinoides (mentioned as Gavelinella), Gaudryina, Pullenia and nodosariids. Bathyal taxa are, for example, Stensioeina, Gyroidinoides, S. cushmani and G. martini. From this comparison it follows that there is greatest similarity (though still limited) with upper bathyal assemblages from North America. Therefore, we suggest that the highly diverse Maastrichtian assemblages of El Kef, northern Egypt, and southern Israel are indicative for a similar upper bathyal $(300-500 \mathrm{~m})$ setting. High proportions of planktonic foraminifera $(>90 \% \mathrm{P})$ concur with such an assignment. In a similar way Keller $(1988 b, 1992)$ inferred upper bathyal-outer neritic depths for assemblages from El Kef and southern Israel. According to Donze et al. (1982) the ostracoda microfauna of El Kef points to a palaeodepth of $400-500 \mathrm{~m}$, whereas Peypouquet et al. (1986) suggested shallower depths $(150-300 \mathrm{~m})$.

Maastrichtian assemblages from Gebel Qreiya and Gebel Duwi, respectively, are increasingly different from the upper bathyal faunas. The combination of a decreasing diversity and proportion of planktonic foraminifera $(80 \% \mathrm{P}$ and $50 \% \mathrm{P}$, respectively) suggests that these localities were situated in shallower parts of the epicontinental basin that covered most of Egypt. 
This view is substantiated by basinwide facies analysis (Hendriks et al. 1987; Luger 1988) and palaeogeographic reconstructions (Said $1990 a, b)$. Gebel Qreiya was situated in an outer shelf environment, whereas Gebel Duwi was part of a shallower inner to middle neritic part of the basin (Hendriks et al. 1987: Luger 1988). In conclusion, the Gebel Qreiya assemblage may indicate $100-150 \mathrm{~m}$ palaeodepth, whereas the Gebel Duwi assemblage is indicative for an even shallower palaeodepth $(50-100 \mathrm{~m})$.

Although various studies have been performed on the distribution of Palaeocene benthic foraminifera in Tunisia (Aubert \& Berggren 1976; Salaj et al. 1976; Saint-Marc \& Berggren 1988; Saint-Marc 1993), very little has been documented on Maastrichtian distributions. To our knowledge, only one paper briefly describes Maastrichtian benthic foraminifera from an area $50 \mathrm{~km}$ southeast of El Kef (Said 1978); taxonomically the fauna shows considerable similarity to the one from El Kef. Without any more data from Tunisia, we cannot assess whether a palaeobathymetrically biofacial arrangement, similar to the one in Egypt, is present in Tunisia. However, since most of the shallow water taxa of Gebel Qreiya and Gebel Duwi (i.e. Orthokarstenia, A. umboniferus, $P$. aegyptiaca and $N$. canadensis) are also known from the Maastrichtian of West Africa (Petters 1982), it seems plausible that similar neritic assemblages are present in Tunisia. At any rate, the Maastrichtian assemblage of El Kef represents a relatively deep off-shore fauna, that is very similar to the deepest biofacies as seen in Egypt and Israel and has a wide distribution along the southern Tethyan margin.

Upper Maastrichtian planktonic foraminiferal assemblages from El Kef are characterized by a few dominant heterohelicids, whereas globotruncanids are relatively rare compared to open ocean sites (Brinkhuis \& Zachariasse 1988; Keller 1988a; Nederbragt 1991). This planktonic assemblage, together with the $\delta^{13} \mathrm{C}$ record and oceanic circulation models, has been interpreted to reflect high fertility in surface waters induced by (possibly intermittent) coastal upwelling (Parish \& Curtis 1982; Reiss 1988; Keller \& Lindinger 1989; Kroon \& Nederbragt 1990; Nederbragt 1992). The resulting high organic carbon flux to the sea-floor may have favoured the most common taxa, such as Heterostomella spp., Sitella spp. and G. martini. A preference for a high nutrient supply of these taxa could explain why they are usually infrequent or even absent in more oligotrophic deep-sea assemblages. The presence of $E$. subsculptura in outer neritic to middle bathyal assemblages from mid latitude ODP and DSDP sites has been interpreted to indicate more eutrophic deep water regimes (Widmark 1995). The high relative abundance $(>20 \%)$ of this species in Nahal Avdat may indicate similar trophic conditions there as well. High nutrient availability may also explain why many other common bathyal taxa, such as $G$. beccariiformis, $C$. hyphalus, Nuttallides truempyi and Gyroidinoides globosus, that are associated with more oligotrophic deep-sea environments (Van Morkhoven et al. 1986; Widmark \& Malmgren $1992 b$ ), were absent at southern Tethyan upper bathyal depths during the late Maastrichtian.

Judging from the high diversity of the benthic assemblage, a severe oxygen minimum zone (OMZ) did not develop at this depth, despite the inferred high organic carbon flux; concomitant oxygen advection was apparently sufficient to prevent the ecosystem from high stress levels. Our interpretation of trophic conditions and palaeoxygenation at the sea-floor during the late Maastrichtian concurs well with inferences from ostracoda assemblages. The ostracod microfauna points to slightly depressed oxygen saturation $\left(4.5 \mathrm{ml} / 1 \mathrm{O}_{2}\right)$ in a weakly developed $\mathrm{OMZ}$, that probably resulted from high, upwelling related, surface productivity (Donze et al. 1982; Peypouquet et al. 1986).

\section{Earliest Palaeocene}

The rather peculiar lowermost Palaeocene assemblage of El Kef has, to our knowledge, not been identified from any other area. An exception might be one of the assemblages encountered by Said (1978); this author noted the presence of abundant $B$. quadrata-ovata and Cibicidoides alleni (which might correspond to our $C$. pseudoacutus) next to several Nodosariacea in lower(most) Palaeocene faunas. Without more detailed information we can, however, only speculate whether this assemblage is similar to the one from El Kef. Aubert \& Berggren (1976) studied 160 samples from nine Palaeocene sequences, located in central Tunisia, but apparently none of them yielded an assemblage similar to ours from El Kef, although there are several species in common. The following common species in the lowermost Palaeocene of El Kef were not encountered in other localities in Tunisia: Anomalinoides ekblomi, $A$. aubertae, Pseudouvigerina sp. 1, A. wilcoxensis and Gyroidinoides sp. 1 (Aubert \& Berggren 1976). Ammomarginulina aubertae and A. ekblo$m i$ have been recorded in boreal areas (Brotzen 1948; Gradstein \& Kaminski 1989; Kuhn 1992), while we observed Pseudouvigerina sp. 1 in the 
lowermost Palaeocene of a $\mathrm{K} / \mathrm{Pg}$ boundary profile in the Maastrichtian type-area (unpubl. data).

Of all assemblages studied, the Maastrichtian and the lower Palaeocene faunas of Gebel Qreiya show the greatest similarity with the lowermost Palaeocene fauna of El Kef. The presence and proportion of several SA 4 taxa, such as $C$. pseudoacutus and B. strobila, next to $B$. quadrata-ovata and Osangularia plummerae, is striking. On the other hand, they differ in the presence of SA 2 taxa, such as $C$. abudurbensis, $V$. depressa, $G$. octocameratus and Oridorsalis plummerae next to several shallow water taxa, that are more common in Gebel Duwi. Moreover, all SA 5 taxa, except $A$. midwayensis, are absent in Gebel Qreiya. Despite these differences, these shallow outer neritic (100-150 m) Egyptian assemblages show the best correspondence, and it could be argued that the lowermost Palaeocene assemblage of $\mathrm{El} \mathrm{Kef}$ also indicates such palaeodepths (cf. Keller 1988b, 1992). Unfortunately, it is not possible to infer an independent palaeodepth estimate by means of ostracoda; during the earliest Palaeocene seafloor redox conditions entirely control the composition of the assemblages (Donze et al. 1982; Peypouquet et al. 1986).

Low diversity, high dominance (C. pseudoacutus) and reduced numbers of burrowing organisms, judging from the preserved laminations, strongly suggest considerable oxygen deficiency at the sea-floor during the earliest Palaeocene. The abundance of Tappanina selmensis (up to $30 \%$ ) in the $63-595 \mu \mathrm{m}$ size fraction also suggested depressed oxygenation during the lowermost Palaeocene (Speijer 1992). Elsewhere, neritic and bathyal low diversity assemblages dominated by $T$. selmensis, have been considered to indicate oxygen deficiency as well (Olsson \& Wise 1987; Thomas 1990b; Gibson et al. 1993; Gibson \& Bybell 1995). The two samples from the base of the boundary clay $(\mathrm{K} / \mathrm{Pg}+1.2$ and $3.6 \mathrm{~cm})$ show a unique spike of B. quadrata-ovata. In morphological features this taxon is very similar to the modern Globobulimina. The latter is able to live deep within the sediment where it feeds on degraded organic matter and/or associated bacteria under nearly anoxic conditions (Corliss 1985; Buzas et al. 1993; Jorissen et al. 1994). Bulimina quadrata-ovata may have adopted a similar strategy; peak values of this species coinciding with a peak in total organic carbon (TOC) content (3$5 \%$; Keller \& Lindinger 1989), suggest that this taxon was relatively successful in coping with oxygen deficient conditions. The subsequent decrease in $B$. quadrata-ovata and TOC sig- nalled slightly better ventilation, which favoured the proliferation of the epibenthic $C$. pseudoacutus. These conditions appear to have been fairly stable until the early Palaeocene, although a sharp decrease in SA 5 taxa $1 \mathrm{~m}$ above the $\mathrm{K} / \mathrm{Pg}$ boundary (at the base of the $C$. taurica Subzone) marks a second order faunal change. This purely quantitative change in the benthic assemblage coincides with a minor rise in planktonic foraminiferal numbers and $\% \mathrm{P}$, and with a compositional turnover in the pelagic ecosystem, interpreted to reflect elevated nutrient levels in surface waters (Brinkhuis \& Zachariasse 1988). Provided that these elevated nutrient levels were converted into a higher organic carbon flux to the sea-floor, this may indicate that SA 5 taxa were particularly well adapted to minimal food supply under oxygen deficient conditions. More distribution data for these taxa are required to test this hypothesis.

The ostracod record across the $\mathrm{K} / \mathrm{Pg}$ boundary gives support to our interpretation. According to Donze et al. (1982) and Peypouquet et al. (1986), oxygen saturation dropped below $2 \mathrm{ml} / 1$ at the $\mathrm{K} / \mathrm{Pg}$ boundary and it stepped up to $3 \mathrm{ml} / 1$ within the $P$. eugubina Zone. Furthermore, nutrient levels dropped at the $\mathrm{K} / \mathrm{Pg}$ boundary and remained relatively low within the $P$. eugubina Zone.

\section{Early Palaeocene}

Faunas similar to the ones in the lower Palaeocene of El Kef, Wadi Nukhl and Nahal Avdat have also been recorded in other localities of northern Egypt, southern Israel and Tunisia (Said \& Kenawy 1956; Aubert \& Berggren 1976; Benjamini et al. 1992; Keller 1992). Many of the species (e.g. Anomalinoides spp., Cibicidoides spp., Gyroidinoides spp., Osangularia plummerae and $P$. prima) belong to the neritic Midway Fauna (Berggren \& Aubert 1975). In contrast, G. beccariiformis is a typical Late CretaceousPalaeocene deep-sea species (Tjalsma \& Lohmann 1983; Van Morkhoven et al. 1986), but it has also been observed in deposits from locally subsided basins in Tunisia (Aubert \& Berggren 1976; Saint-Marc \& Berggren 1988). The common presence of $G$. beccariiformis, next to low frequencies of other deep-sea species present in the lower Palaeocene (e.g. Angulogavelinella avnimelechi and Nuttallides sp., that are lumped in 'trochospiral rest') indicate a palaeodepth of $200-400 \mathrm{~m}$, which is in agreement with Tunisian palaeobathymetrical models (Saint-Marc \& Berggren 1988; Saint-Marc 1993), and with a palaeobathymetric estimate based on ostracoda (Donze et al. 1982). Based on the same ostracod 
dataset, Peypouquet et al. (1986) inferred a 75$150 \mathrm{~m}$ palaeodepth for this interval. Keller $(1988 b)$ interpreted even shallower depths (50$100 \mathrm{~m}$ ), but abandoned this view in a later paper (Keller 1992). Palaeodepth estimates shallower than $200 \mathrm{~m}$ are in conflict with the well established Palaeocene upper depth limit of $G$. beccariiformis (Van Morkhoven et al. 1986). Already during the Maastrichtian $G$. beccariiformis was a ubiquitous cosmopolitan deep-sea species (e.g. Dailey 1983; Thomas 1990b; Nomura 1991; Widmark \& Malmgren 1992b), and it has only been recorded in considerable numbers in deeper bathyal deposits of the Tethys (e.g. in Spain: Keller 1992; in Austria and Romania: unpubl. data). These distribution patterns suggest that $G$. beccariiformis acquired a shallower upper depth limit in the early Palaeocene.

The lower Palaeocene assemblages of Gebel Qreiya and Gebel Duwi show a strong resemblance with neritic assemblages from central Egypt and Tunisia (Aubert \& Berggren 1976; Luger 1985; Saint-Marc \& Berggren, 1988; Saint-Marc 1993). At Gebel Qreiya the palaeodepth was probably between 100 and $150 \mathrm{~m}$, whereas Gebel Duwi was still somewhat shallower $75-100 \mathrm{~m}$, although $\mathrm{P} / \mathrm{B}$ ratios in these localities suggest more similar palaeodepths.

The sequential (re-)appearance of many taxa and the resulting diversification in El Kef clearly reflects progressive amelioration of the bottom environment. Increasing oxygen levels are also suggested by the more intensively bioturbated sediments. The return of only the less common Maastrichtian taxa and the appearance of the deep-sea marker G. beccariiformis, inferred to be an indicator of more oligotrophic conditions, may point at a slightly reduced food supply to the sea-floor compared to the late Maastrichtian. The $\delta^{13} \mathrm{C}$ record as well as PFN values support this view. Assemblages of planktonic foraminifera and dinoflagellates also suggest a return to more stable conditions and higher nutrient availability (Brinkhuis \& Zachariasse 1988). Based on the appearance of Parakrithe, Donze et al. (1982) and Peypouquet et al. (1986) speculated on high nutrient levels due to intermittent upwelling within the $P$. pseudobulloides Zone. Their data show, however, that this change did not occur at the base of this zone but higher up. Since we only studied the basal $7 \mathrm{~m}$ (of in total $40 \mathrm{~m}$ ) of the $P$. pseudobulloides Zone, our interpretation of nutrient levels matches with the ostracoda record. Ostracodbased palaeoxygenation, however, is incompatible with our interpretation, since oxygen levels in the lower part of the P. pseudobulloides Zone were considered to be as low as within the $P$. eugubina Zone.

\section{Discussion}

\section{Sea-level change across the K/Pg boundary}

Successive cycle charts and eustatic sea-level curves by the EXXON group (Vail et al. 1977; Haq et al. 1987, 1988; Donovan et al. 1988) as well as the sea-level curve established for El Kef (Brinkhuis \& Zachariasse 1988) have played a central role in the discussion on sea-level related $\mathrm{K} / \mathrm{Pg}$ boundary extinctions (e.g. Brinkhuis \& Zachariasse 1988; Keller 1988a,b, 1989a, b, 1992; Schmitz 1988; Keller et al. 1990; MacLeod \& Keller 1991 a, b; Rohling et al. 1991; Habib et al. 1992; Schmitz et al. 1992). In the cycle chart by Vail et al. (1977) a major eustatic sea-level fall, in the order of $150-200 \mathrm{~m}$, marks the $\mathrm{K} / \mathrm{Pg}$ boundary, which is followed by a gradual rise in the early Palaeocene. A large number of papers is in support of a longer term sea-level fall or regression at the close of the Cretaceous (e.g. Hancock \& Kauffman 1979; Matsumoto 1980; Ekdale \& Bromley 1984; Hultberg \& Malmgren 1986; Peypouquet et al. 1986). Other studies support a sharp sea-level fall close to the boundary, followed by sea-level rise during the earliest Palaeocene (e.g. Jones et al. 1987; Brinkhuis \& Zachariasse 1988; Habib et al. 1992; Moshkovitz \& Habib 1993).

In the revised cycle chart (Haq et al. 1987, 1988) a prominent $100 \mathrm{~m}$ sea-level fall is situated well below the $\mathrm{K} / \mathrm{Pg}$ boundary ( $G$. contusa Zone; sequence boundary age $68 \mathrm{Ma}$ ), and is followed by a rapid $75 \mathrm{~m}$ eustatic rise. A relatively minor fall $(10-20 \mathrm{~m})$ marks the uppermost Maastrichtian (A. mayaroensis Zone; sequence boundary at $67 \mathrm{Ma}$ ) and is followed by a $25 \mathrm{~m}$ sea-level rise from the $\mathrm{K} / \mathrm{Pg}$ boundary onwards. Based on a study in Braggs, Alabama, Donovan et al. (1988) modified this part of the cycle chart of Haq et al. $(1987,1988)$ in such a way that the relative magnitudes of these two sea-level events were switched, so that the major sea-level event corresponds to the $67 \mathrm{Ma}$ sequence boundary. Few papers (e.g. Flexer \& Reyment 1989; Schmitz et al. 1992) have provided independent (palaeontological) data suggesting sea-level rise or transgression across the $\mathrm{K} / \mathrm{Pg}$ boundary.

At $\mathrm{El} \mathrm{Kef}$ both the relative abundance of land-derived sporomorphs and the proportion of nearshore groups of dinoflagellates (Spiniferites and Cyclonephelium) suggest a marked sealevel fall starting some $50 \mathrm{~cm}(\approx 12 \mathrm{ka})$ below the boundary and culminating in the $\mathrm{K} / \mathrm{Pg}$ boundary interval (Brinkhuis \& Zachariasse 1988). 
Highest relative numbers of sporomorphs and nearshore dinoflagellates are found between $20 \mathrm{~cm}$ above and below the boundary (and also between 50 and $85 \mathrm{~cm}$ above the $\mathrm{K} / \mathrm{Pg}$ boundary). Based on these frequency patterns Brinkhuis \& Zachariasse (1988) erected a relative sealevel curve for El Kef with shallowest conditions in the $\mathrm{K} / \mathrm{Pg}$ boundary interval, followed by a gradually rising, though fluctuating, sea-level in the earliest Palaeocene.

Our analysis of benthic foraminiferal assemblages from the upper $30 \mathrm{~m}$ of upper Maastrichtian of El Kef reveals no particular trend that can be related to either shallowing or deepening. Even in a relatively deep water site as El Kef eustatic sea-level variations in the order of 50$100 \mathrm{~m}$ as suggested by Donovan et al. (1988) would result in a distinct pattern of taxonomic replacement and frequency changes. Therefore, we can only conclude that such sea-level variations did not occur in El Kef within the studied part of the upper Maastrichtian. Moreover, both the rather stable benthic assemblages as well as the continuously high $\mathrm{P} / \mathrm{B}$ ratios in the uppermost $4.5 \mathrm{~m}$ of the Maastrichtian also argue against a major sea-level fall at the end of the Cretaceous. A refined foraminifera-based palaeobathymetrical distribution model for the late Maastrichtian southern Tethys is required to trace minor sea-level events as suggested by Haq et al. $(1987,1988)$ in El Kef. Without such refinement we cannot be conclusive with respect to possible low amplitude sea-level variations. Also, since Brinkhuis \& Zachariasse (1988) do not indicate the relative magnitude of sea-level change across the $\mathrm{K} / \mathrm{Pg}$ boundary, we are unable to test their hypothesis by means of alternative, foraminifera-based, palaeobathymetrical analyses.

Independently of Brinkhuis \& Zachariasse (1988), Keller (1988b) argued for a significant sea-level fall at the $\mathrm{K} / \mathrm{Pg}$ boundary because of the disappearance of many upper bathyal to outer neritic benthic foraminifera. In a later paper the results of El Kef are discussed in a wider, Tethyan context (Keller 1992). In that paper much credit is given to the sea-level curve of Brinkhuis \& Zachariasse (1988), which as outlined above, indicates falling sea-level at least up to the boundary (i.e. to the base of the boundary clay). The turnover in Tethyan benthic foraminifera, however, is related to a pre-boundary sea-level rise and resulting OMZ expansion (Keller 1992). Since at the same time the upper Maastrichtian assemblages are considered to indicate greater depths than the lowermost Palaeocene assemblages (Keller 1992), this scenario appears rather contradictory.
We agree with Keller (1988b) that the faunal change at the $\mathrm{K} / \mathrm{Pg}$ boundary may suggest a significant shallowing. However, according to our palaeodepth estimates a very rapid shallowing of at least $150 \mathrm{~m}$ up to $400 \mathrm{~m}$ would be required to explain these faunal changes independently of any other parameters. Furthermore, this apparent lowstand of sea-level would have persisted well into the early Palaeocene i.e. until outer neritic and upper bathyal taxa reappeared. Such prolonged sea-level lowstand is incompatible with the sea-level curve of either Brinkhuis \& Zachariasse (1988) or Haq et al. (1987, 1988), nor does the sedimentary record show any signs of erosion or redeposited shallow water sediments which could be expected with a sea-level fall of that magnitude.

\section{Quasi-palaeobathymetrical faunal change}

In previous discussions it was shown that the benthic faunal changes reflect fundamental ecosystem alterations. In our view these are not necessarily related to sea-level change. The tight coincidence between faunal change and proxy records for oxygenation and productivity suggests a more complex situation. Food and oxygen supply are generally considered to be the fundamental parameters that determine the overall composition of benthic foraminiferal assemblages (e.g. Harman 1964; Van der Zwaan 1982; Lutze \& Coulbourn 1984; Jorissen 1987; Corliss \& Chen 1988; Sjoerdsma \& Van der Zwaan 1992; Sen Gupta \& Machain-Castillo 1993). Palaeoecological model simulations predict that a significant change in either one of these parameters could result in considerable community alteration, e.g. reflecting a quasibathymetrical change (Sjoerdsma \& Van der Zwaan 1992). The 'delta effect' in the Gulf of Mexico (Pflum \& Frerichs 1976) might be the expression of such a change. It was shown that in the Mississippi delta front the bathymetrical distribution of many species differs significantly from the distribution in other parts of the Gulf of Mexico: enhanced food supply and variation in other environmental parameters generated these modifications.

Examples from the fossil record of deep water community turnover and temporal replacement by a shallow water community, are documented for the deep-sea extinction event at the end of the Palaeocene (Thomas 1990a, $b$; Speijer \& Van der Zwaan 1994). At Maud Rise (Southern Ocean; $1500-2000 \mathrm{~m}$ palaeodepth) a low diversity assemblage dominated by $T$. selmensis temporarily replaced the highly diverse late Palaeocene deep-sea assemblage (Thomas 
1990b). Tappanina selmensis occurs more often in bathyal deposits, but it is typically a neritic species (Van Morkhoven et al. 1986; Gibson \& Bybell 1995). This faunal change has been related to deep-sea oxygen deficiency in the latest Palaeocene, favouring the more tolerant and opportunistic species $T$. selmensis (Thomas $1990 b$ ). A similar faunal response was observed in Wadi Nukhl; at the end of the Palaeocene this site had deepened to $500-700 \mathrm{~m}$ and a highly diverse upper-middle bathyal benthic assemblage flourished (Speijer 1995). Within a sapropelitic bed this fauna was temporarily but abruptly replaced by a low diversity assemblage dominated by Anomalinoides aegyptiacus, a species that typifies middle neritic deposits in southern and eastern Egypt (Speijer \& Van der Zwaan 1994; Speijer et al. 1996). As at Maud Rise, oxygen deficiency played an important role here. A similar faunal response to changing trophic and redox conditions, unrelated to a significant sea-level fluctuation, may have occurred as well at $\mathrm{El}$ Kef during the $\mathrm{K} / \mathrm{Pg}$ boundary transition. We realise, however, that proposing a similar scenario for El Kef is rather speculative and more detailed information from shallower deposits in Tunisia is required to test this hypothesis.

In a similar way we interpret the apparent deepening during the early Palaeocene primarily as reflecting gradual ecosystem restoration, closely following ameliorating redox and trophic conditions. Restoration started with the remigration of many Lazarus taxa (probably from deeper waters) in an otherwise rather empty ecospace. Subsequent immigration of other taxa eventually led to the development of a normal Palaeocene upper bathyal fauna that is present in many places along the north African continental margin.

Although sea-level variations (Haq et al. 1987 , 1988; Brinkhuis \& Zachariasse 1988) may have played a role within the studied interval as well, we believe that these were not instrumental in the prominent palaeoenvironmental changes during the earliest-early Palaeocene. Thus, rather than depth controlled faunal changes, we suggest that major perturbations in oxygen and food supply determined a quasi-palaeobathymetrical faunal sequence.

\section{Tethyan continental margin productivity and oxygen deficiency}

Basically, the results from El Kef can be reduced into signals of two main palaeoenvironmental events: at the $\mathrm{K} / \mathrm{Pg}$ boundary a sudden drop in productivity (surface and bottom) and reduced bottom oxygenation, followed by gradual recovery during the early Palaeocene. The surface productivity failure appears to have been an ocean-wide phenomenon (Perch-Nielsen et al. 1982; Hsü \& McKenzie 1985; Arthur et al. 1987; Meyers \& Simoneit 1989; Stott \& Kennett 1989; Zachos et al. 1989), although at several high latitude sites this seems not to be the case (Hollis 1993; Keller 1993; Barrera \& Keller 1994). Restoration of ocean productivity up to preboundary levels is thought to have taken place over a time-span of $0.3-1.5 \mathrm{Ma}$ (Arthur et al. 1987; Stott \& Kennett 1989; Zachos et al. 1989). This time-span probably stretches beyond our record of El Kef; several productivity proxies indeed indicate that pre-boundary levels were not reached within the studied time interval. Earliest Palaeocene oxygen deficiency also seems to have been a widespread phenomenon, in particular in Tethyan marginal basins (Magaritz et al. 1985; Lahodynsky 1988; Schmitz 1988; Wiedmann 1988; Kaijwara \& Kaiho 1992; Sarkar et al. 1992; Kuhnt \& Kaminski 1993; Coccioni \& Galeotti 1994), although quite variable in duration.

Oxygen concentrations at the sea-floor depend on the balance between oxygen supply and consumption (e.g. Demaison \& Moore 1980). Below the mixed layer oxygen is supplied through turbulent mixing and advection, whereas it is consumed by degradation of organic matter and respiration (e.g. Southam et al. 1982). Furthermore, oxygen solubility decreases with increasing temperature and aging of the water, i.e. longer exposure to organic breakdown, results in decreasing oxygen contents. There is considerable evidence that supply of organic matter from Tethyan surface waters was greatly reduced during the earliest Palaeocene. In spite of this, oxygen concentration at the sea-floor was depressed; therefore we can only conclude that the oxygen supply to intermediate waters also strongly diminished. We speculate that the production of Tethyan intermediate water was curtailed at the $\mathrm{K} / \mathrm{Pg}$ boundary, perhaps as a result of climatic perturbations at low-middle latitudes, triggered by the impact of an extraterrestrial object and amplified by various feedback mechanisms.

\section{Extinction and survivorship selectivity}

In El Kef, the extinction of many species in the earliest Palaeocene is related to both oxygen deficiency and nutrient limitations. As conditions ameliorated in the early Palaeocene, half the number of taxa that became locally extinct at the $\mathrm{K} / \mathrm{Pg}$ boundary, were able to re-occupy a 
niche. Meanwhile, many other species had become extinct, although at least some (e.g. $C$. incrassata gigantea and $C$. beaumontianus) persisted a while longer in the early Palaeocene.

Although it may be argued that widespread oxygen deficiency was the prime cause for benthic extinctions in Tethyan margin localities as El Kef and Caravaca (see Coccioni \& Galeotti 1994), it cannot account for extinctions in the deep-sea. There, oxygen concentration of bottom waters appears to have remained normal (Thomas 1990a, 1992; Nomura 1991; Widmark \& Malmgren 1992a). Another mechanism must account for these extinctions.

Our data suggest extinction selectivity between various morphogroups: elongate $\mathrm{bi}$-/triserial taxa appear more severely affected than trochospiral taxa. In modern environments abundance of the bi-/triserial morphogroup (in particular, Bulimina, Bolivina and Stainforthia) is often related to depressed oxygen levels, enhanced food levels, or to a combination of both (e.g. Van der Zwaan 1982; Lutze \& Coulbourn 1984; Corliss \& Chen 1988; Sen Gupta \& Machain-Castillo 1993; Rathburn \& Corliss 1994). In a general sense, there also appears to be a relationship between test-shape and microhabitats: low trochospiral forms are usually found to live on the sediment surface, whereas elongate bi-/triserial forms often occupy a habitat within the sediment (Corliss 1985, 1991; Corliss \& Chen 1988; but see also Barmawidjaja et al. 1992; Linke \& Lutze 1993; Rathburn \& Corliss 1994). Combining these morphogroup-environment relationships has led to the suggestion that the amount of organic carbon within the sediment may determine the abundance of endobenthic (and thus often bi- -1 triserial) taxa (Rathburn \& Corliss 1994).

Three aspects of benthic extinction selectivity in the earliest Palaeocene suggest that the longterm surface productivity crisis, starting at the $\mathrm{K} / \mathrm{Pg}$ boundary was the prime controlling parameter. (1) Shallower more eutrophic environments show a more distinct turnover and a greater loss in number of species than oligotrophic deeper waters (Thomas 1990b; Kaiho 1992). (2) Many of the species that became extinct were rather common in these more eutrophic environments. This is particularly clear in our data from El Kef and Gebel Duwi. (3) Species that are supposed to have lived within organic carbon-rich sediments were most prone to extinction. Elongate endobenthic taxa (e.g. Coryphostoma, Sitella, Bolivinoides, Orthokarstenia, Pyramidina and Eouvigerina) were much more severely affected than trochospiral taxa. This pattern observed earlier by Keller
(1992), is very consistent in upper bathyal as well as neritic assemblages: despite the much higher number of trochospiral taxa in our dataset, we record only four extinctions in this morphogroup, against ten in the bi-/triserial morphogroup.

The pelagic productivity crisis not only caused a decrease in the amount of food supply to the sea-floor, but also a reduction in nutrient heterogeneity, as evidenced by widely recognized oligotaxic algal blooms of, for example, Thoracosphaera and Braarudosphaera, that characterize the earliest Palaeocene (Romein $1979 a, b$; Perch-Nielsen et al. 1982; AlcalaHerrera et al. 1992; Pospichal 1994). Since some recent foraminifera are considered to be selective feeders (e.g. Lee 1974; Murray 1991), it seems likely that at least some extinctions may be due to this reduction of nutrient heterogeneity.

With the present data we can only speculate on where the Lazarus taxa (SA 2) of El Kef survived, but most likely the majority survived in deep-sea environments unaffected by oxygen deficiency. Taxa such as $G$. pyramidata, $P$. plummerae, $V$. depressa and Pullenia spp. are indeed widely documented from Upper Cretaceous and Palaeocene deep-sea deposits (e.g. Sliter 1977a, $b$; Dailey 1983; Thomas 1990b; Nomura 1991; Widmark \& Malmgren 1992b). These taxa were unable to withstand dysoxic conditions at El Kef, but were probably less dependent on the amount and heterogeneity of the food supply than the species that eventually became extinct.

\section{Conclusions}

The $\mathrm{K} / \mathrm{Pg}$ boundary succession of $\mathrm{El} \mathrm{Kef}$ provides a distinct sequence of sudden ecosystem collapse followed by gradual recovery. A severe reduction of oxygenation and trophic resources on the sea-floor invoked temporal replacement of a stable upper bathyal palaeocommunity by one primarily consisting of more tolerant and opportunistic shallow water taxa. Gradual amelioration of the environment was followed by the settlement of a normal Palaeocene upper bathyal fauna, very different from the Maastrichtian one.

In contrast to the deep-sea, shallow palaeocommunities were severely affected by the $\mathrm{K} / \mathrm{Pg}$ event. Many taxa that are thought to have been dependent on high and heterogeneous nutrient resources (in particular endobenthic deposit feeders) suffered extinction most severely during the earliest Palaeocene. The differential effects in various bathymetrical compartments and ecolo- 
gical groups result from a prolonged period of reduced surface fertility, that started at the $\mathrm{K} / \mathrm{Pg}$ boundary.

We thank Alexandra Nederbragt and Jan Smit for providing samples, Anders Henriksson for calcareous nannoplankton determinations, and Peter Luger for enabling us to study his sample collection from Egypt. RPS thanks his late friend Albert Langejans for all computer hardware and software support and advice. Constructive criticism by Henk Brinkhuis and Norman MacLeod improved the quality of the manuscript. An earlier version of this paper was part of the first author's doctoral thesis.

\section{Appendix 1.}

Discussions on taxonomy and synoymies are beyond the general scope of this volume. For more information on these topics we refer the reader to the taxonomy section of an earlier version of this paper in the first author's doctoral thesis (Speijer 1994, p. 44-64). Here we confine ourselves to listing the primary references of the species discussed in this paper. Alabamina wilcoxensis Toulmin, 1941, p. 603, pl. 81, figs 10-14.

Ammomarginulina aubertae Gradstein \& Kaminski, 1989, p. 74, pl. 3, figs 1-8; pl. 4, figs 13; text-fig. 2.

Anomalinoides cf. acutus $($ Plummer) $=\mathrm{cf}$. Anomalina ammonoides (Reuss) var. acuta Plummer, 1926 , p. 149 , pl. 10, fig. 2.

Anomalinoides affinis (Hantken) $=$ Pulvinulina affinis Hantken, 1875, p. 78, pl. 10, fig. 6.

Anomalinoides ekblomi (Brotzen) $=$ Cibicides ekblomi Brotzen, 1948, p. 82, pl. 13, fig. 2.

Anomalinoides praeacutus $($ Vasilenko) $=$ Anomalina praeacuta Vasilenko, 1950, p. 208, pl. 5, figs 2,3 .

Anomalinoides rubiginosus $($ Cushman $)=$ Anomalina rubiginosa Cushman, 1926, p. 607, pl. 21, fig. 6.

Anomalinoides simplex $($ Brotzen $)=$ Cibicides simplex Brotzen, 1948, p. 83, pl. 13, figs 4, 5.

Anomalinoides umboniferus (Schwager) $=$ Discorbis umbonifer Schwager, 1883, p. 126, pl. 27, fig. 14.

Anomalinoides susanaensis (Browning) $=$ Cibicides susanaensis Browning (in Mallory), 1959, p. 271, pl. 32, figs $11,12$.

Bolivinoides decoratus (Jones) $=$ Bolivina decorata Jones, 1886, p. 330, pl. 27, figs 7, 8.

Bolivinoides draco draco (Marsson) $=$ Bolivina draco Marson, 1878, p. 157, pl. 3, fig. 25.

Bolivinopsis clotho (Grzybowski) = Bolivinopsis? clotho (Grzybowski) in: Cushman, 1946, p. 103, pl. 44, figs 10-13.
Bulimina strobila Marie, 1941, p. 265, pl. 32, fig. 302.

Cibicides beaumontianus (D'Orbigny) $=$ Truncatulina beaumontiana D'Orbigny, 1840, p. 35, pl. 3, figs 17-19.

Cibicidoides abudurbensis $($ Nakkady) $=$ Cibicides abudurbensis Nakkady, 1950, p. 691, pl. 90, figs 35-38.

Cibicidoides cf. hyphalus (Fisher) $=$ cf. Anomalinoides hyphalus Fisher, 1969, p. 197, pl. 3. $(\mathrm{pc})=$ planoconvex morphology; $(\mathrm{bc})=$ biconvex morphology.

Cibicidoides pseudoacutus (Nakkady) $=$ Anomalina pseudoacuta Nakkady, 1950, p. 691, pl. 90, figs 29-32.

Cibicidoides suzakensis (Bykova) $=$ Cibicides suzakensis Bykova in: Salaj et al. 1976, p. 158, pl. 16 , figs 7,8 .

Coryphostoma incrassata gigantea (Wicher)= Bolivina incrassata Reuss var. gigantea Wicher, 1956, p. 120, pl. 12, figs 2-3.

Coryphostoma plaitum $($ Carsey $)=$ Bolivina plaitum Carsey, 1926, p. 26, pl. 4, fig. 2.

Eouvigerina subsculptura McNeil \& Caldwell, 1981, p. 231, pl. 18, figs 20, 21.

Elhasaella cf. allanwordi Hamam $=\mathrm{cf}$. Elhasaella allanwoodi Hamam, 1976, p. 454, pl. 1, figs 1-7; pl. 2, figs 1-8.

Gaudryina pyramidata Cushman $=$ Gaudryina laevigata Franke var. pyramidata Cushman, 1926 , p. 587 , pl. 16 , fig. 8 .

Gavelinella beccariiformis (White) $=$ Rotalia beccariiformis White, 1928, p. 287, pl. 39, figs 2-4.

Gavelinella martini $($ Sliter $)=$ Gyroidinoides quad ratus martini Sliter, 1968, p. 121, pl. 22, fig. 9.

Gyroidinoides girardanus (Reuss) $=$ Rotalina girardana Reuss, 1851, p. 73, pl. 5, fig. 34.

Gyroidinoides octocameratus (Cushman \& Hanna) $=$ Gyroidina soldanii D'Orbigny octocamerata Cushman \& Hanna, 1927, p. 223, pl. 14, figs 16-18.

Gyroidinoides tellburmaensis Futyan, 1976, p. 532, pl. 81, figs 10-12.

Loxostomoides applinae (Plummer) $=$ Bolivina applini Plummer, 1926, p. 69, pl. 4, fig. 1.

Neobulimina canadensis Cushman \& Wickenden, 1928 , p. 13, pl. 1, figs 1-2.

Oridorsalis plummerae $($ Cushman $)=$ Eponides plummerae Cushman, 1948, p. 44, pl. 8, fig. 9.

Orthokarstenia oveyi (Nakkady) = Siphogenerinoides oveyi Nakkady, 1950 , p. 686 , pl. 89, fig. 20.

Osangularia plummerae Brotzen, 1940 , p. 30 , text-fig. 8.

Praebulimina reussi Morrow $=$ Bulimina reussi Morrow, 1934, p. 195, pl. 29, fig. 12.

Pseudoeponides $c f$. elevatus (Plummer) $=\mathrm{cf}$. Truncatulina elevatus Plummer, 1926, p. 142, 
pl. 11, fig. 1.

Pseudouvigerina plummerae Cushman, 1927, p. 115, pl. 23, fig. 8.

Pulsiphonina prima $($ Plummer $)=$ Siphonina prima Plummer, 1926, p. 148, pl. 12, fig. 4.

Pyramidina aegyptiaca (Nakkady) $=$ Reussella aegyptiaca Nakkady, 1950 , p. 687, pl. 90, fig. 1. Sitella colonensis (Cushman \& Hedberg) $=$ Buliminella colonensis Cushman \& Hedberg, 1930, p. 65, pl. 9, figs 6, 7.

Sitella cushmani (Sandidge) $=$ Buliminella cush mani Sandidge, 1932, p. 280, pl. 42, figs 18, 19.

Sitella fabilis (Cushman \& Parker) = Buliminella fabilis Cushman \& Parker, 1936, p. 7, pl. 2, fig. 5. Tappanina selmensis $($ Cushman $)=$ Bolivinita selmensis Cushman, 1933, p. 58, pl. 7, figs 3-4.

Valvalabamina depressa (Alth) $=$ Gyroidina depressa (Alth) in: Cushman, 1946, p. 139, pl. 58, figs $1-4$.

Stensioeina pommerana Brotzen, 1936, p. 165.

\section{References}

Aleala-Herrera, J. A., Grossman, E. L. \& GartNER, S. 1992. Nannofossil diversity and equitability and fine-fraction $\delta^{13} \mathrm{C}$ across the Cretaceous-Tertiary boundary at Walvis Ridge Leg 74, South Atlantic. Marine Micropaleontology, 20, 77-88.

Alvarez, L. W., Alvarez, W., Asaro, F. \& Michel, H. V. 1960. Extraterrestrial cause for the Cretaceous-Tertiary extinction. Science, 208, 1095-1108.

ARChibald, J. D. \& BryaNT, L. J. 1990. Differential Cretaceous/Tertiary extinctions of nonmarine vertebrates; evidence from northeastern Montana. In: SHARPTON, V. L. \& WARD, P. D. (eds) Global Catastrophes in Earth History. An Interdisciplinary Conference on Impacts, Volcanism, and Mass Mortality. Geological Society of America Special Paper, 247, 549-562.

ARThur, M. A., ZACHOS, J. C. \& Jones, D. S. 1987. Primary productivity and the Cretaceous/Tertiary boundary event in the oceans. Cretaceous Research, 8, 43-54.

Aubert, J. \& Berggren, W. A. 1976. Paleocene benthic foraminiferal biostratigraphy and paleoecology of Tunisia. Bulletin de Centre de Rechèrche Pau-SNPA, 10, 379-469.

Barmadwidjaja, D. M., Jorissen, F. J., PušKarić, S. \& VAN DER ZWAAN, G. J. 1992. Microhabitat selection by benthic foraminifera in the northern Adriatic Sea. Journal of Foraminiferal Research, 22, 297-317.

Barrera, E. \& Keller, G. 1994. Productivity across the Cretaceous/Tertiary boundary in high latitudes. Geological Society of America Bulletin, 106, 1254-1266.

Benjamini, C., Keller, G. \& Perelis-Grossovicz, L. 1992. On benthic foraminiferal paleoenvironments across the $\mathrm{K} / \mathrm{T}$ boundary, Negev, Israel.
In: SARnThein, M., ThIEde, J. \& ZAHN, R. (eds) Fourth International Conference on Paleoceanography, ICP IV; Short- and Long-Term Global Change: Records and Modelling. 21-25 September 1992, Kiel/Germany, Program and Abstracts. GEOMAR Report 15, GEOMAR, Kiel, Germany, 61 .

Berger, W. H. \& Diester-HaAss, L. 1988. Paleoproductivity; the benthic/planktonic ratio in foraminifera as a productivity index. Marine Geology, $81,15-25$.

Berggren, W. A. \& Aubert, J. 1975. Paleocene benthonic foraminiferal biostratigraphy, paleobiogeography and paleoecology of Atlantic-Tethyan regions; Midway-type fauna. Palaeogeography, Palaoeclimatology, Palaeoecology, 18, 73-192.

, Kent, D. V., Swisher, C. C. III \& Aubry, M. P. 1995. A revised Cenozoic geochronology and chronostratigraphy. In: BERGGREN, W. A., Kent, D. V., Aubry, M. P. \& HARDENBol, J. (eds) Geochronology, Time Scales and Stratigraphic Correlations: Framework for an Historical Geology. Society for Economic Paleontologists and Mineralogists, Special Publication, 54, 129212.

Bramlette, M. M. \& Martini, E. 1964. The great change in calcareous nannoplankton fossils between the Maestrichtian and Danian. Micropaleontology, 10, 291-322.

Brinkhuis, H. \& Zachariasse, W. J. 1988. Dinoflagellate cysts, sea level changes and planktonic foraminifers across the Cretaceous-Tertiary boundary at El Haria, Northwest Tunisia. Marine Micropaleontology, 13, 153-191.

, Romein, A. J. T., Smit, J. \& ZaChariasse, J.-W. 1994. Danian-Selandian dinoflagellate cysts from lower latitudes with special reference to the El Kef section, NW Tunisia. GFF, 116, 46-48.

Brotzen, F. 1936. Foraminiferen aus dem schwedischen, untersten Senon von Eriksdal in Schonen. Sveriges Geologiska Undersökning Serie $C, 30$.

1940. Flintrännans och Trindelrännans geologi (Öresund)-Die Geologie der Flint- und Trindelrinne (Öresund). Sveriges Geologiska Undersökning Serie $C, 34,1-33$.

1948. The Swedish Paleocene and its foraminiferal fauna. Sveriges Geologiska Undersökning Serie $C, 42$.

Buzas, M. A., Culver, S. J. \& Jorissen, F. J. 1993. A statistical evaluation of the microhabitats of living (stained) infaunal benthic foraminifera. In: LANGER, M. R. (ed.) Foraminiferal Microhabitats, Marine Micropaleontology, 20, 311-320.

CarseY, D. O. 1926. Foraminifera of the Cretaceous of central Texas. Texas University, Bulletin, 2612.

Coccioni, R. \& GaleotTI, S. 1994. K-T boundary extinction: Geologically instantaneous or gradual event? Evidence from deep-sea benthic foraminifera. Geology, 22, 779-782.

Corliss, B. H. 1985. Microhabitats of benthic foraminifera within deep-sea sediments. Nature, 314, 435-438. 
1991. Morphology and microhabitat preferences of benthic foraminifera from the Northwest Atlantic Ocean. Marine Micropaleontology, 17, 195-236.

- \& CHEN, C. 1988. Morphotype patterns of Norwegian Sea deep-sea benthic foraminifera and ecological implications. Geology, 16, 716-719.

Cushman, J. A. 1926. The Foraminifera of the Velasco shale of the Tampico embayment San Luis Potosi, Mexico. AAPG Bulletin, 10, 581-612.

1927. New and interesting foraminifera from Mexico and Texas. Contributions from the Cushman Laboratory for Foraminiferal Research, 3, 111-117.

1933. New American Cretaceous foraminifera. Contributions from the Cushman Laboratory for Foraminiferal Research, 9, 49-64.

1946. Upper Cretaceous foraminifera of the Gulf coastal region of the United States and adjacent areas. United States Geological Survey, Professional Paper, 206.

- 1948. Additional new foraminifera from the American Paleocene. Contributions from the Cushman Laboratory for Foraminiferal Research, 24, 43-45.

\& HanNA, G. D. 1927. Foraminifera from the Eocene near Coalinga, California. California Academy of Science, Proceedings, 4th Series, 16, 205-228.

_ \& Hedberg, H. D. 1930. Notes on some foraminifera from Venezuela and Colombia. Contributions from the Cushman Laboratory for Foraminiferal Research, 6, 64-69.

- \& PARKER, F. L. 1936. Notes on some Cretaceous species of Buliminella and Neobulimina. Contributions from the Cushman Laboratory for Foraminiferal Research, 12, 5-10.

— \& WICKENDEN, R. T. D. 1928. A new foraminiferal genus from the Upper Cretaceous. Contributions from the Cushman Laboratory for Foraminiferal Research, 4, 12-13.

DAILEY, D. H. 1983. Late Cretaceous and Paleocene benthic foraminifers from Deep Sea Drilling Project Site 516, Rio Grande Rise, western South Atlantic Ocean. In: BARKER, P. J., CARLSON, R. L., JOHNSON, D. A. et al. (eds) Initial reports of the Deep Sea Drilling Project. 72, U.S. Government Printing Office, Washington, DC, 757-782.

Demaison, G. J. \& MoOre, G. T. 1980. Anoxic environments and oil source bed genesis. $A A P G$ Bulletin, 64, 1179-1209.

D'HondT, S. \& Keller, G. 1991. Some patterns of planktic foraminiferal assemblage turnover at the Cretaceous-Tertiary boundary. Marine Micropaleontology, 17, 77-118.

Donovan, A. D., Baum, G. R., BlechSChMIDT, G. L., Loutit, T. S., Pflum, C. E. \& VaIl, P. R. 1988. Sequence stratigraphic setting of the CretaceousTertiary boundary in central Alabama. In: WIL GUS, C. K. et al. (eds) Sea-Level Changes: An Integrated Approach. Society for Economic Paleontologists and Mineralogists, Special Publication, 42, 299-307.

Donze, P., Colin, J. P., Damotte, R., Oerthi, H. J.,
Peypouquet, J. \& SaID, R. 1982. Les ostracodes du Campanien terminal a l'Eocene inférieur de la coupe du Kef, Tunisie Nord-Occidentale. Bulletin des Centres de Rechèrches Exploration-Production Elf Aquitaine, 6, 273-307.

D'OrbigNY, A. 1840. Mémoire sur les foraminifères de la craie blanche du bassin de Paris. Société de Géologie de France, Mémoire, 4, 1-51.

Ekdale, A. A. \& BRomley, R. G. 1984. Sedimentology and ichnology of the Cretaceous-Tertiary boundary in Denmark; implications for the causes of the terminal Cretaceous extinction. Journal of Sedimentary Petrology, 54, 681-703.

FARIS, M. 1982. Micropaléontologie et Biostratigraphie du Crétacé Supérieur a l'Eocene Inférieur de l'Egypte Centrale (Région de Duwi, Vallée du Nil, Oasis de Kharga et de Dakhla). Doctorate Thesis, Université de Paris.

Fisher, M. J. 1969. Benthonic foraminifera from the Maestrichtian chalk of Galicia bank, west of Spain. Palaeontology, 12, 189-200.

FleXeR, A. \& ReYMent, R. A. 1989. Note on Cretaceous transgressive peaks and their relation to geodynamic events for the Arabo-Nubian and the northern African shields. Journal of African Earth Sciences, 8, 65-73.

FutYan, A. I. 1976. Late Mesozoic and early Cainozoic benthic foraminifera from Jordan. Palaeontology, 19, 517-537.

Gallagher, W. B. 1991. Selective extinction and survival across the Cretaceous/Tertiary boundary in the Northern Atlantic Coastal Plain. Geology, 19, 967-970.

Gerstel, J., ThunNell, R. \& Ehrlich, R. 1987. Danian faunal succession; planktonic foraminiferal response to a changing marine environment. Geology, 15, 665-668.

Gibson, T. G. \& Bybell, L. M. 1995. Sedimentary patterns across the Paleocene-Eocene boundary in the Atlantic and Gulf Coastal Plains of the United States. In: LAGA, P. (ed.) PaleoceneEocene Boundary Events. Bulletin de la Société belge de Géologie, 103 for 1994, 237-265.

\& OWENS, J. P. 1993. Latest Paleocene lithologic and biotic events in neritic deposits of southwestern New Jersey. Paleoceano-graphy, 8, 495-514.

Gradstein, F. M. \& Kaminski, M. A. 1989. Taxonomy and biostratigraphy of new and emended species of Cenozoic deep-water agglutinated foraminifera from the Labrador and North seas. Micropaleontology, 35, 72-92.

Habib, D., Moshkovitz, S. \& KRAMER, C. 1992. Dinoflagellate and calcareous nannofossil response to sea-level change in Cretaceous-Tertiary boundary sections. Geology, 20, 165-168.

HaNCoCK, J. M. \& KauffMAN, E. G. 1979. The great transgressions of the late Cretaceous. Journal of the Geological Society, London, 136, 175-186.

Hansen, T. A., Farrell, B. R. \& Upshaw, B. III 1993. The first 2 million years after the Cretaceous-Tertiary boundary in East Texas; rate and paleoecology of the molluscan recovery. Paleobiology, 19, 251-265. 
Hantken, M. 1875. Die Fauna der Clavulina SzaboiSchichten; Theil I - Foraminiferen. KöniglichUngarische Geologische Anstalt, Mitteilungen Jahrbuch, Budapest, 4 1-93.

HaQ, B. U., HaRdenbol, J. \& VaIL, P. R. 1987. Chronology of fluctuating sea levels since the Triassic. Science, 235, 1156-1167.

\& - 1988. Mesozoic and Cenozoic chronostratigraphy and cycles of sea level change. In: WILGUS, C. K. et al. (eds) SeaLevel Changes: An Integrated Approach. Society for Economic Paleontologists and Mineralogists, Special Publication, 42, 71-108.

HARMAN, R. A. 1964. Distribution of foraminifera in the Santa Barbara Basin, California. Micropaleontology, 10, 81-96.

Hendriks, F., Luger, P., Bowitz, J. \& Kallenbach, H. 1987. Evolution of depositional environments of SE-Egypt during the Cretaceous and lower Tertiary. Berliner Geowissenschaftliche Abhandlungen, Reihe A: Geologie und Paläontologie, 75, 49-82.

Herguera, J. C. \& Berger, W. H. 1991. Paleoproductivity from benthic foraminifera abundance; glacial to postglacial change in the west-equatorial Pacific. Geology, 19, 1173-1176.

Hollis, C. J. 1993. Latest Cretaceous to late Paleocene radiolarian biostratigraphy; a new zonation from the New Zealand region. In: LAZARUS, D. B. \& De WeVER, P. D. (eds) Interrad VI. Marine Micropaleontology, 21, 295-327.

HsÜ, K. J. \& MCKENZIE, J. A. 1985. A 'strangelove' ocean in the earliest Tertiary. In: SUNDQUIST, E. T. \& Broecker, W. S. (eds) The Carbon Cycle and Atmospheric $\mathrm{CO}_{2}$; Natural Variations Archaean to Present. Geophysical Monograph, 32, AGU, Washington, DC, 487-492.

HUBER, B. T. 1991. Maestrichtian planktonic foraminifer biostratigraphy and the Cretaceous/Tertiary boundary at Hole $738 \mathrm{C}$ (Kerguelen Plateau, southern Indian Ocean). In: BARRON, J. A., Larsen, B. et al. (eds) Proceedings of the Ocean Drilling Program, Scientific Results. 119, ODP, College Station, TX, 451-465.

Hultberg, S. U. \& Malmgren, B. A. 1986. Dinoflagellate and planktonic foraminiferal paleobathymetrical indices in the Boreal uppermost Cretaceous. Micropaleontology, 32, 316-323.

JÄGER, M. 1993. Danian serpulidae and spirorbidae from NE Belgium and SE Netherlands: $K / T$ boundary extinction, survival and origination patterns. Contributions to Tertiary and Quaternary Geology, 29, 73-117.

JONES, T. R. 1886. A list of the Cretaceous foraminifera of Keady Hill, County Derry. Proceedings of the Belfast Nature Field Club, 330.

Jones, D. S., Müller, P. A., Bryan, J. R., Dobson, J. P., Channel, J. E. T., Zachos, J. C. \& ARThur, M. A. 1987. Biotic, geochemical, and paleomagnetic changes across the Cretaceous/Tertiary boundary at Braggs, Alabama. Geology, 15, 311-315.

JORISSEN, F. J. 1987. The distribution of benthic foraminifera in the Adriatic Sea. Marine
Micropaleontology, 12, 21-48.

— BuzAs, M. A., Culver, S. J. \& Kuehl, S. A. 1994. Vertical distribution of living benthic foraminifera in submarine canyons off New Jersey. Journal of Foraminiferal Research, 24, 28-36.

KAIHO, K. 1992. A low extinction rate of intermediate water benthic foraminifera at the Cretaceous/ Tertiary boundary. Marine Micropaleontology, 18, $229-259$.

KaJiwara, Y. \& KaIHo, K. 1992. Oceanic anoxia at the Cretaceous/Tertiary boundary supported by the sulfur isotopic record. Palaeogeography, Palaeoclimatology, Palaeoecology, 99, 151-162.

KELLER, G. 1988a. Biotic turnover in benthic foraminifera across the Cretaceous/Tertiary boundary at El Kef, Tunisia. Palaeogeography, Palaeoclimatology, Palaeoecology, 66, 153-171.

- 1988b. Extinction, survivorship and evolution of planktic foraminifera across the Cretaceous/Tertiary boundary at El Kef, Tunisia. Marine Micropaleontology, 13, 239-263.

1989a. Extended Cretaceous/Tertiary boundary extinctions and delayed population change in planktonic foraminifera from Brazos River, Texas. Paleoceanography, 4, 287-332.

$-1989 b$. Extended period of extinctions across the Cretaceous/Tertiary boundary in planktonic foraminifera of continental-shelf sections; implications for impact and volcanism theories. Geological Society of America Bulletin, 101 14081419.

1992. Paleoecologic response of Tethyan benthic foraminifera to the Cretaceous-Tertiary boundary transition. In: TAKAYANAGI, Y. \& Sarto, T. (eds) Studies in Benthic Foraminifera. Tokai University Press, Tokyo, 77-91.

- 1993. The Cretaceous-Tertiary boundary transition in the Antarctic Ocean and its global implications. Marine Micropaleontology, 21, 1-45.

— \& LINDINGER, M. 1989. Stable isotope, TOC and $\mathrm{CaCO}_{3}$ record across the Cretaceous-Tertiary boundary at El Kef, Tunisia. Palaeogeography, Palaeoclimatology, Palaeoecology, 73, 243-265.

- Barrera, E., Schmitz, B. \& Mattson, E. 1993. Gradual mass extinction, species survivorship, and long-term environmental changes across the Cretaceous-Tertiary boundary in high latitudes. Geological Society of America Bulletin, 105, 979-997.

-, Benjamini, C., Magaritz, M. \& Moshkovirz, S. 1990. Faunal, erosional and $\mathrm{CaCO}_{3}$ events in the early Tertiary eastern Tethys. In: SharPTON, V. L. \& WARD, P. D. (eds) Global Catastrophes in Earth History. An Interdisciplinary Conference on Impacts, Volcanism, and Mass Mortality. GSA Special Paper, 247, 471-480.

Kroon, D. \& NederbraGt, A. J. 1990. Ecology and paleoecology of triserial planktic foraminifera. Marine Micropaleontology, 16, 25-38.

KUHN, W. 1992. Paleozäne und untereozäne BenthosForaminiferen des bayerischen und salzburgischen Helvetikums - Systematik, Stratigraphie und Palökologie. Münchner Geowissenshaftliche 
Abhandlungen, Reihe A: Geologie und Paläontologie, 24.

KuHNT, W. \& KaMINSKI, M. A. 1993. Changes in the community structure of deep water agglutinated foraminifers across the $\mathrm{K} / \mathrm{T}$ Boundary in the Basque basin (Northern Spain). Revista Espanola de Micropaleontologia, 25, 57-92.

LAHODYNSKY, R. 1988. Lithostratigraphy and sedimentology across the Cretaceous-Tertiary boundary in the Flyschgosau, Eastern Alps, Austria. In: Lamolda, M. A., Kauffman, E. G. \& WalliSER, O. H. (eds) Palaeontology and Evolution: Extinction Events. Revista Espanola de Paleontologia, Numero extraordinario, 73-82.

LEE, J. J. 1974. Towards understanding the niche of foraminifera. In: HEDlEY, R. $\mathrm{H}$, et al. (eds) Foraminifera, 1. Academic, New York, 207-260.

LEROY, L. W. 1953. Biostratigraphy of the Maqfi section, Egypt. Geological Society of America, Memoir, 54.

Linke, P. \& Lutze, G. F. 1993. Microhabitat preferences of benthic foraminifera; a static concept or a dynamic adaptation to optimize food aquisition? In: LANGER, M. R. (ed.) Foraminiferal Microhabitats. Marine Micropaleontology, 20, 215-234.

LOEBLICH, A. R. J. \& TAPPAN, H. 1988. Foraminiferal Genera and Their Classification. Van Nostrand Reinhold, New York.

LUGER, P. 1985. Stratigraphie der marinen Oberkreide und des Alttertiärs im südwestlichen ObernilBecken (SW-Ägypten) unter besonderer Berücksichtigung der Mikropaläontologie, Palaöekologie und Paläogeographie. Berliner Geowissenshaftliche Abhandlungen, Reihe A: Geologie und Paläontologie, 63.

1988. Maestrichtian to Paleocene facies evolution and Cretaceous/Tertiary boundary in middle and southern Egypt. In: LAMOLdA, M. A., Kauffman, E. G. \& Walliser, O. H. (eds) Palaeontology and Evolution: Extinction Events. Revista Espanola de Paleontologia, Numero extraordinario, 83-90.

Luterbacher, H. P. \& Premoli-Silva, I. 1964. Biostratigrafia del limite cretaceo-terziario nell'Appennino centrale. Rivista Italiana di Paleontologia, 70, 67-117.

Lutze, G. F. \& CoulbouRN, W. T. 1984. Recent benthic foraminifera from the continental margin of Northwest Africa; community structure and distribution. Marine Micropaleontology, 8, 361401.

MacLeod, N. \& Keller, G. 1991a. Hiatus distributions and mass extinctions at the Cretaceous/ Tertiary boundary. Geology, 19, 497-501.

1991b. How complete are Cretaceous/Tertiary boundary sections? A chronostratigraphic estimate based on graphic correlation. Geological Society of America, Bulletin, 103 1439-1457.

MCNeIL, D. H. \& CAldwell, W. G. E. 1981. Cretaceous rocks and their foraminifera in the Manitoba Escarpment. Geological Association of Canada, Special Paper, 21.

Magaritz, M., Benjamini, C., Keller, G. \&
Moshkovitz, S. 1992. Early diagenetic isotopic signal at the Cretaceous/Tertiary boundary, Israel. Palaeogeography, Palaeoclimatology, Palaeoecology, 91, 291-304.

, Moshkovitz, S., Benjamini, C., Hansen, H. J., Hakansson, E. \& Rasmussen, K. L. 1985. Carbon isotope-, bio- and magnetostratigraphy across the Cretaceous-Tertiary boundary in the Zin Valley, Negev, Israel. Newsletters on Stratigraphy, 15, 100-113.

Mallory, V. S. 1959. Lower Tertiary Biostratigraphy of the California Coast Ranges. American Association of Petroleum Geologists, Tulsa, OK.

MARIE, P. 1941. Les foraminifères de la craie à Belemnitella mucronata $d u$ bassin de Paris. Muséum nationale d'Histoire naturelle, Paris, Mémoir, 12.

MARSSON, T. H. 1878. Die Foraminiferen der weissen Schreibkreide der Insel Rügen. Naturwissenschaftlicher Verein für Neu-Vorpommern und Rügen in Greifswald, 10, 115-196.

MAsters, B. A. 1993. Re-evaluation of the species and subspecies of the genus Plummerita Bronnimann and a new species of Rugoglobigerina Bronnimann (Foraminiferida). Journal of Foraminiferal Research, 23, 267-274.

MAtsumoto, T. 1980. Inter-regional correlation of transgressions and regressions in the Cretaceous period. Cretaceous Research, 1, 359-373.

Meyers, P. A. \& Simonert, B. R. T. 1989. Global comparisons of organic matter in sediments across the Cretaceous/Tertiary boundary. Organic Geochemistry, 16, 641-648.

MoRrow, A. L. 1934. Foraminifera and ostracoda from the Upper Cretaceous of Kansas. Journal of Paleontology, 8, 186-205.

Moshkovitz, S. \& HABIB, D. 1993. Calcareous nannofossil and dinoflagellate stratigraphy of the Cretaceous-Tertiary boundary, Alabama and Georgia. Micropaleontology, 39, 167-191.

MURRAY, J. W. 1991. Ecology and Palaeoecology of Benthic Foraminifera. Elsevier, Amsterdam.

NAKKADY, S. E. 1950. A new foraminiferal fauna from the Esna shales and upper Cretaceous Chalk of Egypt. Journal of Paleontology, 24, 675-692.

NederbraGt, A. J. 1991. Late Cretaceous biostratigraphy and development of Heterohelicidae (planktic foraminifera). Micropaleontology, 37, 329-372.

- 1992. Paleoecology of late Maastrichtian Heterohelicidae (planktic foraminifera) from the Atlantic region. In: MALMgren, B. A. \& BenGTSON, P. (eds) Biogeographic Patterns in the Cretaceous Ocean. Palaeogeography, Palaeoclimatology, Palaeoecology, 92, 361-374.

NomURA, R. 1991. Paleoceanography of upper Maestrichtian to Eocene benthic foraminiferal assemblages at sites 752, 753, and 754, eastern Indian Ocean. In: Weissel, J., Peirce, J. et al. (eds) Proceedings of the Ocean Drilling Program, Scientific Results. 121, ODP, College Station, TX, 3-29.

Nyong, E. E. \& Olsson, R. K. 1984. A paleoslope model of Campanian to lower Maestrichtian 
foraminifera in the North American Basin and adjacent continental margin. Marine Micropaleontology, 80, 437-477.

OLsson, R. K. 1977. Mesozoic foraminifera; western Atlantic. In: SwAIN, F. M. (ed.) Stratigraphic Micropaleontology of Atlantic Basin and Borderlands. Elsevier, Amsterdam, 205-230.

\& LIU, C. 1993. Controversies on the placement of Cretaceous-Paleogene boundary and the $\mathrm{K} / \mathrm{P}$ mass extinction of planktonic foraminifera. Palaios, 8, 127-139.

\& NYONG, E. E. 1984. A paleoslope model for Campanian-lower Maestrichtian foraminifera of New Jersey and Delaware. Journal of Foraminiferal Research, 14, 50-68.

_ \& WISE, S. W. JR. 1987. Upper Paleocene to middle Eocene depositional sequences and hiatuses in the New Jersey Atlantic Margin. In: Ross, C. A. \& Haman, D. (eds) Timing and Depositional History of Eustatic Sequences; Constraints of Seismic Stratigraphy. Cushman Foundation for Foraminiferal Research, Special Publication, 24, 99-112.

Parrish, J. T. \& Curtis, R. L. 1982. Atmospheric circulation, upwelling, and organic-rich rocks in the Mesozoic and Cenozoic eras. Palaeogeography, Palaeoclimatology, Palaeoecology, 40, 31-66.

PERCH-NielseN, K. 1981. Nouvelles observations sur les nannofossiles calcaires à la limite CrétacéTertiaire, près de El Kef, Tunisie. Cahiers de Micropaléontologie, 3 25-36.

$\longrightarrow$, MCKEnZIE, J. A. \& HE, Q. 1982. Biostratigraphy and isotope stratigraphy and the "catastrophic' extinction of calcareous nannoplankton at the Cretaceous/Tertiary boundary. In: SILvER, L. T. \& SChUlTZ, P. H. (eds) Geological Implications of Impacts of Large Asteroids and Comets on the Earth. Geological Society of America Special Paper, 190, 353-371.

PetTers, S. W. 1982. Central West African Cretaceous-Tertiary benthic foraminifera and stratigraphy. Palaeontographica, Abteilung A: Palaeozoologie, Stratigraphie, 179.

Peypouquet, J. P., Grousset, F. \& Mourguiart, P. 1986. Paleoceanography of the Mesogean Sea based on ostracods of the northern Tunisian continental shelf between the Late Cretaceous and Early Paleogene. Geologische Rundschau, 75, 159 174.

Pflum, C. E. \& Frerichs, W. E. 1976. Gulf of Mexico deep-water foraminifers. Cushman Foundation for Foraminiferal Research, Special Publication, 14.

Plummer, H. J. 1926. Foraminifera of the Midway formation in Texas. Texas University, Bulletin, 2644.

Pospichal, J. J. 1994. Cretaceous nannofossils at the $\mathrm{K}-\mathrm{T}$ boundary, El Kef; no evidence for stepwise, gradual, or sequential extinctions. Geology, 22, 99-102.

RATHburN, A. E. \& CoRliss, B. H. 1994. The ecology of the living (stained) deep-sea benthic foraminifera from the Sulu Sea. Paleoceanography, 9, 87150.

RAUP, D. M. \& JABLONSKI, D. 1993. Geography of
end-Cretaceous marine bivalve extinctions. Science, 260, 971-973.

ReISS, Z. 1988. Assemblages from a Senonian highproductivity sea Revue de Paléobiologie, Special Issue, 2, 323-332.

REUSS, A. E. 1851. Die Foraminiferen und Entomostraceen des Kreidemergels von Lemberg. Naturwissenschaftliche Abhandlungen, Wien, 4, 17-52.

Rhodes, M. C. \& Thayer, C. W. 1991. Mass extinctions: ecological selectivity and primary production. Geology, 19, 877-880.

Rohling, E. J., ZACHARIASSE, W. J. \& BRINKhUis, H. 1991. A terrestrial scenario for the CretaceousTertiary boundary collapse of the marine pelagic ecosystem. Terra Nova, 3, 41-48.

RomeIn, A. J. T. 1979a. Cretaceous nannofossils from the Cretaceous/Tertiary boundary interval in the Nahal Avdat Section, Negev, Israel. In: CHrisTENSEN, W. K. \& Birkelund, T. (eds) Symposium on Cretaceous-Tertiary Boundary Events, Proceedings, 2. University of Copenhagen, Copenhagen, Denmark, 202-206.

$1979 b$. Lineages in early Paleogene calcareous nannoplankton. Utrecht Micropaleontological Bulletins, 22.

_ \& SMIT, 1981 The Cretaceous/Tertiary boundary: calcareous nannofossils and stable isotopes. Proceedings of the Koninklijke Nederlandse Akademie van Wetenschappen, Series B, 84, 295-314.

Rosenfeld, A., Flexer, A., Honigstein, A., AlmoGI-LABIN, A. \& DvoraCHEK, M. 1989. First report on a Cretaceous/Tertiary boundary section at Mikhtesh Gadol, southern Israel. Neues Jahrbuch für Geologie und Paläontologie, Monatshefte, 1989, 474-486.

SAID, R. 1978. Étude Stratigraphique et Micropaléontologique du Passage Crétacé-Tertiaire du Synclinal d'Elles (Region Siliana-Sers), Tunisie Centrale, Doctorat $3^{\mathrm{e}}$ Cycle Thesis, Université de Paris.

- 1990a. Cenozoic. In: SAID, R. (ed.) The Geology of Egypt. Balkema, Rotterdam, 451-486. 1990b. Cretaceous paleogeographic maps. In: SAID, R. (ed.) The Geology of Egypt. Balkema, Rotterdam, 439-449.

\& KeNAWY, A. 1956. Upper Cretaceous and lower Tertiary foraminifera from northern Sinai, Egypt. Micropaleontology, 2, 105-173.

SAINT-MARC, P. 1993. Biogeographic and bathymetric distribution of benthic foraminifera in Paleocene El Haria Formation of Tunisia. Journal of African Earth Sciences, 15, 473-487.

- \& BERGGREN, W. A. 1988. A quantitative analysis of Paleocene benthic foraminiferal assemblages in central Tunisia. Journal of Foraminiferal Research, 18, 97-113.

SAlAJ, J. 1978. Contribution à la microbiostratigraphie des hypostratotypes tunisiens du Crétacé supérieur du Danien et du Paléocène. Annales des Mines et de Géologie, 28, 119-145.

1980. Microbiostratigraphie du Crétacé et du Paléogène de la Tunisie Septentrionale et Orientale (Hypostratotypes Tunisiens). Institut Géologique de Dionyz Stúr, Bratislava, Slovakia. 
Pozaryska, K. \& Szczechura, J. 1976. Foraminiferida, zonation and subzonation of the Paleocene of Tunisia. Acta Palaeontologica Polonica, 21, 127-190.

SANDIDGE, J. R. 1932. Foraminifera from the Ripley formation of western Alabama. Journal of Paleontology, 6, 265-287.

Sarkar, A., Bhattacharya, S. K., Shukla, P. N., Bhandari, N. \& NaIdIN, D. P. 1992. Highresolution profile of stable isotopes and iridium across a K/T boundary section from Koshak Hill, Mangyshlak, Kazakhstan. Terra Nova, 4, 585591.

SchMITZ, B. 1988. Origin of microlayering in worldwide distributed Ir-rich marine Cretaceous/Tertiary boundary clays. Geology, 16, 1068-1072.

- - Keller, G. \& Stenvall, O. 1992. Stable isotope and foraminiferal changes across the Cretaceous-Tertiary boundary at Stevns Klint, Denmark: arguments for long-term oceanic stability before and after bolide-impact event. Palaeogeography, Palaeoclimatology, Palaeoecology, 96, 233-260.

SCHWAGER, C. 1883. Die Foraminiferen aus dem Eocänablagerungen der libyschen Wüste und Ägyptens. Palaeontographica, 30, 81-153.

Sen Gupta, B. K. \& Machain-Castrllo, M. L. 1993. Benthic foraminifera in oxygen-poor habitats. In LANGer, M. R. (ed.) Foraminiferal Microhabitats. Marine Micropaleontology, 20, 183-201.

ShahiN, A. 1992. Contribution to foraminiferal biostratigraphy and paleobathymetry of the Late Cretaceous and early Tertiary in the western central Sinai, Egypt. Revue de Micropaléontologie, $35,157-175$.

SharPton, V. L. \& WARD, P. D. 1990. Global Catastrophes in Earth History. An Interdisciplinary Conference on Impacts, Volcanism, and Mass Mortality. Geological Society of America Special Paper, 247.

Sheehan, P. M. \& Fastovsky, D. E. 1992. Major extinctions of land-dwelling vertebrates at the Cretaceous-Tertiary boundary, eastern Montana. Geology, 20, 556-560.

SJoERdSMA, P. G. \& VAN DER ZWAAN, G. J. 1992. Simulating the effect of changing organic flux and oxygen content on the distribution of benthic foraminifers. In: VAN DER ZWAAN, G. J., JOR. ISSEN, F. J. \& ZaChariasse, W. J. (eds) Approaches to Paleoproductivity Reconstructions. Marine Micropaleontology, 19, 163-180.

SLrTER, W. V. 1968. Upper Cretaceous Foraminifera from southern California and northwestern Baja California, Mexico. Kansas University Paleontological Contributions, 49.

- 1977a. Cretaceous benthic foraminifers from the western South Atlantic Leg 39, Deep Sea Drilling Project. In: SUPKo, P. R., PERCHNIELSEN, K. et al. (eds) Initial Reports of the Deep Sea Drilling Project. 39, U.S. Government Printing Office, Washington, DC, 657-697.

- 1977b. Cretaceous foraminifers from the southwestern Atlantic Ocean, Leg 36, Deep Sea Drilling Project. In: BARKeR, P., DALZIEL, I. W.
D. et al. (eds) Initial Reports of the Deep Sea Drilling Project. 36, U.S. Government Printing Office, Washington, DC, 519-573.

\& BAKER, R. A. 1972. Cretaceous bathymetric distribution of benthic foraminifers. Journal of Foraminiferal Research, 2, 167-181.

SMrT, J. 1982. Extinction and evolution of planktonic foraminifera after a major impact at the Cretaceous/Tertiary boundary. In: SILVER, L. T. \& SchULTZ, P. H. (eds) Geological Implications of Impacts of Large Asteroids and Comets on the Earth. Geological Society of America Special Paper, 190, 329-352.

1990. Meteorite impact, extinctions and the Cretaceous-Tertiary boundary. Geologie en Mijnbouw, 69, 187-204.

Southam, J. R., Peterson, W. H. \& Brass, G. W. 1982. Dynamics of anoxia. In: BARRON, E. J. (ed.) Paleogeography and Climate. Palaeogeography, Palaeoclimatology, Palaeoecology, 40, 183-198.

SpeIJeR, R. P. 1992. Benthic foraminiferal response to environmental changes following the $\mathrm{K} / \mathrm{T}$ boundary. In: SARNTHein, M., ThIEde, J. \& ZAHN, R. (eds) Fourth International Conference on Paleoceanography, ICP IV; Short- and LongTerm Global Change: Records and Modelling. 2125 September 1992, Kiel/Germany, Abstracts and Programs. GEOMAR Report 15, GEOMAR, Kiel, Germany, 267-268.

- 1994. Extinction and Recovery Patterns in Benthic Foraminiferal Paleocommunities across the Cretaceous/Paleogene and Paleocene/Eocene Boundaries. Geologica Ultraiectina, 124.

1995. The late Paleocene benthic foraminiferal extinction event as observed in the Middle East. In: LAGA, P. (ed.) Paleocene-Eocene Boundary Events. Bulletin de la Société belge de Géologie, 103 for 1994, 267-280.

\& VAN DER ZWAAN, G. J. 1994. The differential effect of the Paleocene/Eocene boundary event: extinction and survivorship in shallow to deep water Egyptian benthic foraminiferal assemblages. In: SPEIJER, R. P. (ed.) Extinction and Recovery Patterns in Benthic Foraminiferal Paleocommunities across the Cretaceous/Paleogene and Paleocene/Eocene Boundaries. Geologica Ultraiectina, 124, 121-168.

\& SCHмrTz, B. 1996. The impact of Paleocene/Eocene boundary events on middle neritic benthic foraminiferal assemblages from Egypt. Marine Micropaleontology, in press.

STOTT, L. D. \& KeNNETT, J. P. 1989. New constraints on early Tertiary palaeoproductivity from carbon isotopes in foraminifera. Nature, 342, 526-529.

SUTHERLAND, F. L. 1994. Volcanism around K/T boundary time - its role in an impact scenario for the K/T extinction events. Earth Science Reviews, 36, 1-26.

Thomas, E. 1990a. Late Cretaceous-early Eocene mass extinctions in the deep sea. In: SHARPTON, V. L. \& WARD, P. D. (eds) Global Catastrophes in Earth History. An Interdisciplinary Conference on Impacts, Volcanism, and Mass Mortality. GSA Special Paper, 247, 481-496. 
1990b. Late Cretaceous through Neogene deep-sea benthic foraminifers (Maud Rise, Weddell Sea, Antarctica). In: BARKER, P. F., KENNETT, J. P. et al. (eds) Proceedings of the Ocean Drilling Program, Scientific Results. 113, ODP, College Station, TX, 571-594.

1992. Cenozoic deep-sea circulation: evidence from deep-sea benthic foraminifera. $A G U$ Antarctic Research Series, 56, 141-165.

Tualsma, R. C. \& LohmanN, G. P. 1983. PaleoceneEocene bathyal and abyssal benthic foraminifera from the Atlantic Ocean. Micropaleontology, Special Publication, 4.

Toulmin, L. D. JR. 1941. Eocene smaller Foraminifera from the Salt Mountain limestone of Alabama. Journal of Paleontology, 15, 567-611.

VAIL, P. R., Mrtchum, R. M. \& Thompson, S. III 1977. Global cycles of relative changes of sea level. In: PAYToN, C. E. (ed.) Seismic Stratigraphy-Applications to Hydrocarbon Exploration. American Association of Petroleum Geologists, Memoir, 26, 83-97.

VAN DER ZWAAN, G. J. 1982. Paleoecology of late Miocene Mediterranean foraminifera. Utrecht Micropaleontological Bulletins, 25. , JoRisSEN, F. J. \& DE STIGTER, H. C. 1990. The depth dependency of planktonic/benthic foraminiferal ratios: Constraints and applications. Marine Geology, 95, 1-16.

$-\longrightarrow$ \& Zachariasse, W. J. 1992. Approaches to Paleoproductivity Reconstructions. Marine Micropaleontology, 19. Elsevier, Amsterdam.

VAN Morkhoven, F. P. C. M., Berggren, W. A. \& Edwards, A. S. 1986. Cenozoic cosmopolitan deep-water benthic foraminifera. Bulletin des Centres de Recherches Exploration-Production Elf Aquitaine, Memoir, 11.

VAsIlenKo, V. P. 1950. Paleocene foraminifera of the central part of the Dnieper-Donets basin. In: Microfauna of the U.S.S.R. 4, Trudy, VNIGRI, Kavkaz, 177-224 [in Russian].

VERBEEK, J. W. 1977. Calcareous nannoplankton biostratigraphy of Middle and Upper Cretaceous deposits in Tunisia, southern Spain and France. Utrecht Micropaleontological Bulletins, 16.

WhITE, M. P. 1928. Some index Foraminifera of the Tampico Embayment area of Mexico (part 1, 2). Journal of Paleontology, 2, 177-215, 280-316.

Wicher, C. A. 1956. Die Gosau-Schichten in Becken von Gams (Österreich) und die Foraminiferengliederung der hoheren Oberkreide in der Tethys. Paläontologisches Zeitschrift, Sonderhefte, 30, 87136.

WIDMARK, J. G. V. 1995. Multiple deep-water sources and trophic regimes in the latest Cretaceous deep sea: evidence from benthic foraminifera. Marine Micropaleontology, 26, 361-384.

\& Malmaren, B. A. 1992a. Benthic foraminiferal changes across the Cretaceous/Tertiary boundary in the deep sea; DSDP sites 525, 527, and 465. Journal of Foraminiferal Research, 22, 81-113.

1992b. Biogeography of terminal Cretaceous deep-sea benthic foraminifera from the Atlantic and Pacific oceans. In: MALMGREN, B. A. \& Bengtson, P. (eds) Biogeographic Patterns in the Cretaceous Ocean. Palaeogeography, Palaeoclimatology, Palaeoecology, 92, 375-405.

WiedmanN, J. 1988. The Basque coastal sections of the $\mathrm{K} / \mathrm{T}$ boundary; a key to understanding mass extinction in the fossil record. In: LAMOLDA, $\mathbf{M}$. A., Kauffman, E. G. \& Walliser, O. H. (eds) Palaeontology and Evolution: Extinction Events. Revista Espanola de Paleontologia, Numero extraordinario, 127-140.

Wonders, A. A. H. 1980. Middle and Late Cretaceous planktonic foraminifera of the western Mediterranean area. Utrecht Micropaleontological Bulletins, 24.

Zachos, J. C., Arthur, M. A. \& Dean, W. E. 1989. Geochemical evidence for suppression of pelagic marine productivity at the Cretaceous/Tertiary boundary. Nature, 337, 61-64. 